\title{
Development of Single Retinofugal Axon Arbors in Normal and $\beta 2$ Knock-Out Mice
}

\author{
Onkar S. Dhande, ${ }^{1,2}$ Ethan W. Hua, ${ }^{3}$ Emily Guh, ${ }^{2}$ Jonathan Yeh, ${ }^{2}$ Shivani Bhatt, ${ }^{2}$ Yueyi Zhang, ${ }^{2}$ Edward S. Ruthazer, ${ }^{4}$ \\ Marla B. Feller, ${ }^{5}$ and Michael C. Crair ${ }^{2}$ \\ ${ }^{1}$ Program in Developmental Biology, Baylor College of Medicine, Houston, Texas 77030, 2Department of Neurobiology, Yale University, New Haven, \\ Connecticut 06510, ${ }^{3}$ Division of Biological Sciences, University of California, San Diego, California 92093, ${ }^{4}$ Montreal Neurological Institute, McGill \\ University, Montreal, Quebec, Canada, H3A 2B4, and ${ }^{5}$ Department of Molecular and Cell Biology and Helen Wills Neuroscience Institute, University of \\ California at Berkeley, Berkeley, California 94720
}

The maturation of retinal ganglion cell (RGC) axon projections in the dorsal lateral geniculate nucleus (dLGN) and the superior colliculus (SC) relies on both molecular and activity-dependent mechanisms. Despite the increasing popularity of the mouse as a mammalian visual system model, little is known in this species about the normal development of individual RGC axon arbors or the role of activity in this process. We used a novel in vivo single RGC labeling technique to quantitatively characterize the elaboration and refinement of RGC axon arbors in the dLGN and SC in wild-type (WT) and $\beta 2$-nicotinic acetylcholine receptors mutant $\left(\beta 2^{-1-}\right)$ mice, which have perturbed retinal waves, during the developmental period when eye-specific lamination and retinotopic refinement occurs. Our results suggest that eye-specific segregation and retinotopic refinement in WT mice are not the result of refinement of richly exuberant arbors but rather the elaboration of arbors prepositioned in the proper location combined with the elimination of inappropriately targeted sparse branches. We found that retinocollicular arbors mature $\sim 1$ week earlier than retinogeniculate arbors, although RGC axons reach the dLGN and SC at roughly the same age. We also observed striking differences between contralateral and ipsilateral RGC axon arbors in the SC but not in the LGN. These data suggest a strong influence of target specific cues during arbor maturation. In $\beta 2^{-1-}$ mice, we found that retinofugal single axon arbors are well ramified but enlarged, particularly in the SC, indicating that activity-dependent visual map development occurs through the refinement of individual RGC arbors.

\section{Introduction}

The development of retinofugal projections has served as a fundamental model system for examining the factors that govern the formation of sensory maps. Retinal ganglion cell (RGC) axons project to their primary targets in the brain, the dorsal lateral geniculate nucleus of the thalamus (dLGN) and the superior colliculus (SC), in which they undergo significant refinement to form a precise retinotopic map during early development. RGC projections from both eyes initially overlap within the SC and dLGN and subsequently segregate into non-overlapping and ad-

Received Sept. 17, 2010; revised Nov. 12, 2010; accepted Dec. 14, 2010.

This work was supported by National Institutes of Health Grants R01 MH62639, R01 EY015788, and P30 EY000785 (M.C.C.) and R01 EY013528 (M.B.F.). M.C.C. also gratefully acknowledges the support of the family of William Ziegler III. The pCAG - gapEGFP plasmid was a gift from Dr. S. McConnell (Stanford University, Stanford, CA). pCAG-LNL-mRFP1 was a gift from Dr. A. Chenn (Northwestern University, Evanston, IL). We thank Anne Schohl (Montreal, Quebec, Canada) for validating the two-plasmid Cre/loxP strategy in pilot studies and Xiakang Han and Crair laboratory members for technical support. Illustrations were made by Mark Saba (Photo + Design, Yale University, New Haven, (T).

0.S.D. developed the technique, performed experiments examining retinocollicular and retinogeniculate axons, and helped draft the manuscript. E.W.H. performed experiments examining retinogeniculate axons and helped draft the manuscript. E.G., J.Y., and S.B. helped reconstruct axonal arbors. Y.Z. modified plasmids for electroporation. E.S.R. suggested use of a two-plasmid Cre/loxP strategy and helped draft the manuscript. M.B.F. and M.C.C. participated in the design of the study and helped coordinate and draft the manuscript.

Correspondence should be addressed to Michael C. Crair, 333 Cedar Street, SHM B301, Yale University School of Medicine, New Haven, CT 06510. E-mail: michael.crair@yale.edu.

DOI:10.1523/JNEUROSCI.4899-10.2011

Copyright $\odot 2011$ the authors $\quad 0270-6474 / 11 / 313384-16 \$ 15.00 / 0$ jacent regions leading to the emergence of eye-specific domains. The development of maps for retinotopy and eye of origin are known to depend on cues provided by both molecular factors and spontaneous retinal activity (McLaughlin and O'Leary, 2005; Huberman et al., 2008a). However, we lack a detailed description of the normal maturation of single retinofugal projections during the acquisition of retinotopy and eye-specific segregation in mice, and the precise roles of molecular and activity-dependent factors in the maturation of individual retinal ganglion cell arbors remains poorly understood.

Mice lacking the $\beta 2$ subunit of nicotinic acetylcholine receptors (nAChRs) $\left(\beta 2^{-/-}\right)$have altered patterns of spontaneous retinal activity during development and have become a popular model system for examining the role of activity in the emergence of retinotopy and eye segregation in the SC and dLGN (Rossi et al., 2001; Muir-Robinson et al., 2002; Grubb and Thompson, 2003; McLaughlin et al., 2003; Chandrasekaran et al., 2005; Mrsic-Flogel et al., 2005; Huberman et al., 2008b; Shah and Crair, 2008; Stafford et al., 2009; Triplett et al., 2009). Experiments using bulk retinofugal axon labeling techniques in $\beta 2^{-/-}$mice reveal enlarged RGC target zones and impaired eye-specific segregation in the dLGN and SC. These mapping defects are thought to be caused by RGC axon refinement errors, leading to enlarged arbors and consequently enlarged termination zones. However, there is no direct evidence for enlarged RGC axon arbors in $\beta 2^{-l-}$ mice, and other scenarios could potentially explain the 
mapping errors. For example, perturbed retinal waves in $\beta 2^{-1-}$ mice could lead to a shift in the position of an axon arbor relative to neighboring axons without affecting its single axon arborization pattern, as appears to occur in the zebrafish RGC activity mutant macho (Gnuegge et al., 2001). Changes in retinal activity levels in $\beta 2^{-1-}$ mice could also interfere with basic cellular processes that regulate axon growth, elongation, and branching, producing mapping defects because of sparse, poorly ramified individual RGC axon arbors rather than failures in refinement (Torborg and Feller, 2005; Chalupa, 2009).

We sought to disambiguate these various scenarios through the examination of single RGC axon arbors in wild-type (WT) and $\beta 2^{-1-}$ mice during development. Here we demonstrate a simple in vivo electroporation technique for labeling single RGCs with fluorescent proteins in a spatially and temporally restricted manner in mice. Analysis of single ipsilateral and contralateral RGC axon arbors with this technique in the SC and dLGN reveals that the process of eye-specific segregation and retinotopic refinement occurs through the progressive ramification of branches in the appropriate target region along with the elimination of inappropriately located sparse branches. Interestingly, there is a temporal mismatch in the development of retinofugal arbors in the dLGN and SC, with RGC arbors ramifying in the dLGN almost 1 week after they have already formed dense termination zones in the SC. Moreover, ipsilateral arbors in the SC are quite sparse relative to contralateral axons but grossly similar in the dLGN at eye-opening [approximately postnatal day 14 (P14)]. Finally, we show RGC axon arbors in the dLGN and SC of $\beta 2^{-l-}$ mice have a similar number of branch points as WT mice but are dramatically enlarged in the SC, with more muted effects in the dLGN. Together, these experiments illustrate the use of a powerful new tool to examine single RGC axon development, describe the course of normal RGC axon arbor development in the mouse dLGN and SC, and reveal the profound effect of spontaneous patterned retinal activity on the development of single retinofugal axon arbors.

\section{Materials and Methods}

In vivo electroporation. WT and $\beta 2$ knock-out mice $\left(\beta 2^{-1-}\right)$ on a C57BL/6 background were used in this study. $\beta 2^{-1-}$ mice were genotyped as described previously by Xu et al. (1999). P0-P5 pups were anesthetized by hypothermia, whereas mice older than $\mathrm{P} 5$ were anesthetized with an intraperitoneal injection of a mixture of ketamine (4.28 $\mathrm{mg} / \mathrm{ml})$, xylazine $(0.82 \mathrm{mg} / \mathrm{ml})$, and acepromazine $(0.07 \mathrm{mg} / \mathrm{ml})$. After surgically opening the eyelid, the eye was protruded, and a focal injection $(\sim 2.3-4.6 \mathrm{nl})$ of plasmid DNA solution was made into the retina beneath the scleral margin through a glass pipette attached to a nanoinjector (Fig. 1A) (Nanoinject II; Drummond Scientific). Only one injection of plasmid DNA (described below) in the each eye was made per mouse. Dumont \#5 forceps (Fine Science Tools) were modified to be used as electrodes by first breaking one prong at the base of the handle and then soldering wires to each prong, which are now electrically isolated. The modified forceps were put back together with a plastic spacer between the two prongs to provide spring action. The electrode tips were placed over the injection site, and square pulses were applied across the electrodes using an electrical stimulator (Fig. 1 $A^{\prime}$ ) (Grass Instruments). Square pulses of $25 \mathrm{~V}$ strength, 50 ms duration, $1 \mathrm{~s}$ apart were used. Ten pulses (five pulses of each polarity) were applied for mice older than $\mathrm{P} 4$, and six pulses (three pulses of each polarity) were applied for $\mathrm{P} 0-\mathrm{P} 1$ mice.

Electroporation strategies and plasmid constructs. Two strategies were used to label retinal neurons with fluorescent proteins. First, we used a construct encoding enhanced green fluorescent protein (EGFP) under the control of a CAG promoter (chicken $\beta$-actin promoter with a cytomegalovirus immediate early enhancer). EGFP is tagged with the palmi- toylation sequence of growth associated protein-43 (GAP-43) targeting it to the cell membrane (mut4EGFP) (Okada et al., 1999). This construct is referred to as PCAG-gapEGFP.

The second strategy used to label cells consists of a combination of two constructs and was based on the Cre/loxP system. The first was a Cre recombinase expression vector (Addgene plasmid 13775) (Matsuda and Cepko, 2007), and the second vector contained a floxed STOP cassette followed by membrane-targeted monomeric red fluorescent protein 1 (mRFP1) or EGFP. Both plasmids were under the control of a CAG promoter and are referred to as pCAG-Cre and pCAG-LNL-XFP (XFP is either membrane targeted mRFP1 or EGFP). pCAG-Cre $(\sim 0.15-1$ $\mathrm{ng} / \mu \mathrm{l}$ ) was used at $\sim 1000-10,000$-fold lower concentration than $\mathrm{pCAG}-$ LNL-gapXFP $(\sim 1-2 \mu \mathrm{g} / \mu \mathrm{l})$, confining strong XFP expression to a small number of cells (by virtue of the relatively low pCAG-Cre concentration). The coding sequence for GFP was excised with EcoRI and NotI from pCALNL-GFP (Addgene plasmid 13770) (Matsuda and Cepko, 2007). The coding sequence for gapEGFP was PCR amplified from pCAG-gapEGFP using the following primers: $5^{\prime}$-ACTCTAGA ATTCATGCTGTGCTGTATGAGAAGA- $3^{\prime}$ and $5^{\prime}$-ACTTCAGCGGCCGCTTACT TGTACAGCTCGTCCA- $3^{\prime}$. The amplified product was cloned into pCALNL to generate the pCAG-LNL-gapEGFP plasmid. gapmRFP1 was generated by PCR from pCALNL-mRFP1 as a template using the following primers: $5^{\prime}$ ACTCATGAATTCATGCTGTGCTGTATGAGAAGAACCAAACAGGTTCATGGCCTCCTCCACCAAAAGATCATGGCCTCCTCCGAGGAC-3' (palmitoylation sequence of GAP-43 was added to the primer) and $5^{\prime}$ ACTCTAGC GGCCGCCTAGGCGCCGGTGGAGTGGCG-3'. The PCR product was cloned into pCALNL to generate PCAG-LNL-gapmRFP1.

For both strategies, single RGC labeling was observed at all ages, ranging from P2 to P25, with strong XFP labeling in RGCs by $24 \mathrm{~h}$ after electroporation and maintained expression for at least 3 weeks after transfection. The number of cells expressing XFP was dictated by the volume of plasmid solution injected. At all ages, in $\sim 90 \%$ of cases, a small volume injection $(\sim 2.3-4.6 \mathrm{nl})$ led to expression in a few RGCs, and in $\sim 15 \%$ of the trials, only single RGCs were labeled (Fig. 1C-F) (see Fig. $4 A^{\prime}$ ) (supplemental Figs. $1 B-D, 2 B$, available at www.jneurosci.org as supplemental material)

Tissue preparation and immunostaining. One to $10 \mathrm{~d}$ after electroporation, animals were killed, and the electroporated eye was removed along with the optic nerve and briefly fixed in $4 \%$ paraformaldehyde (PFA) in $1 \times$ PBS. Flattened whole-mount electroporated retina and the optic nerve were imaged using an epifluorescence microscope (Carl Zeiss) to screen for animals with successful RGC labeling (Fig. $1 A^{\prime \prime}$ ).

To visualize retinogeniculate axons, either the protocol described below for retinocollicular axons was used or the following protocol was used. Briefly, brains were removed and fixed with $4 \%$ PFA overnight and then cryoprotected by sinking in $30 \%$ sucrose in $0.01 \mathrm{~m} \mathrm{PBS}$ for $24 \mathrm{~h}$. One hundred micrometer coronal brain sections were cut with a freezing sliding microtome (American Optical Company). Whole-mount retinas and brain sections were washed in $0.01 \mathrm{~m}$ PBS, then blocked with $2 \%$ normal donkey serum, $2 \%$ bovine serum albumin, and $0.3 \%$ Triton $\mathrm{X}-100$ in $0.01 \mathrm{~m}$ PBS for $2 \mathrm{~h}$ at room temperature, and then incubated in blocking solution for $18 \mathrm{~h}$ at $4^{\circ} \mathrm{C}$. Next, tissue was washed in $0.01 \mathrm{M}$ PBS and subsequently incubated with secondary antibody in blocking solution for $1 \mathrm{~h}$ at room temperature. After a final $0.01 \mathrm{M}$ PBS wash, tissue was mounted in Vectashield with 4',6-diamidino-2-phenylindole (Vector Laboratories).

To visualize retinocollicular axons, brains perfused with $1 \times$ PBS were fixed overnight in 4\% PFA. Fixed brains were mounted in 3\% agarose and sectioned sagittally at $250 \mu \mathrm{m}$ using a vibratome (VT1000S; Leica). Immunohistochemistry was performed on free-floating brain sections and retinal whole mounts to amplify the XFP signal. Briefly, the tissue was permeabilized with $1 \%$ Triton X-100 in PBS for 20 min, incubated with $0.1 \mathrm{~m}$ glycine for $1 \mathrm{~h}$, and then blocked with $10 \%$ normal goat serum and $5 \%$ BSA in PBS containing $0.05 \%$ Triton X-100 overnight at $4^{\circ} \mathrm{C}$. Sections were then incubated in primary antibody in blocking solution at $4^{\circ} \mathrm{C}$ for $3 \mathrm{~d}$. Sections were washed five times in $0.01 \%$ Triton X-100 and incubated in secondary antibody in blocking solution for $2 \mathrm{~h}$. After washing four times with $1 \times$ PBS, sections were mounted with Fluromount-G (Electron Microscopy Sciences). 

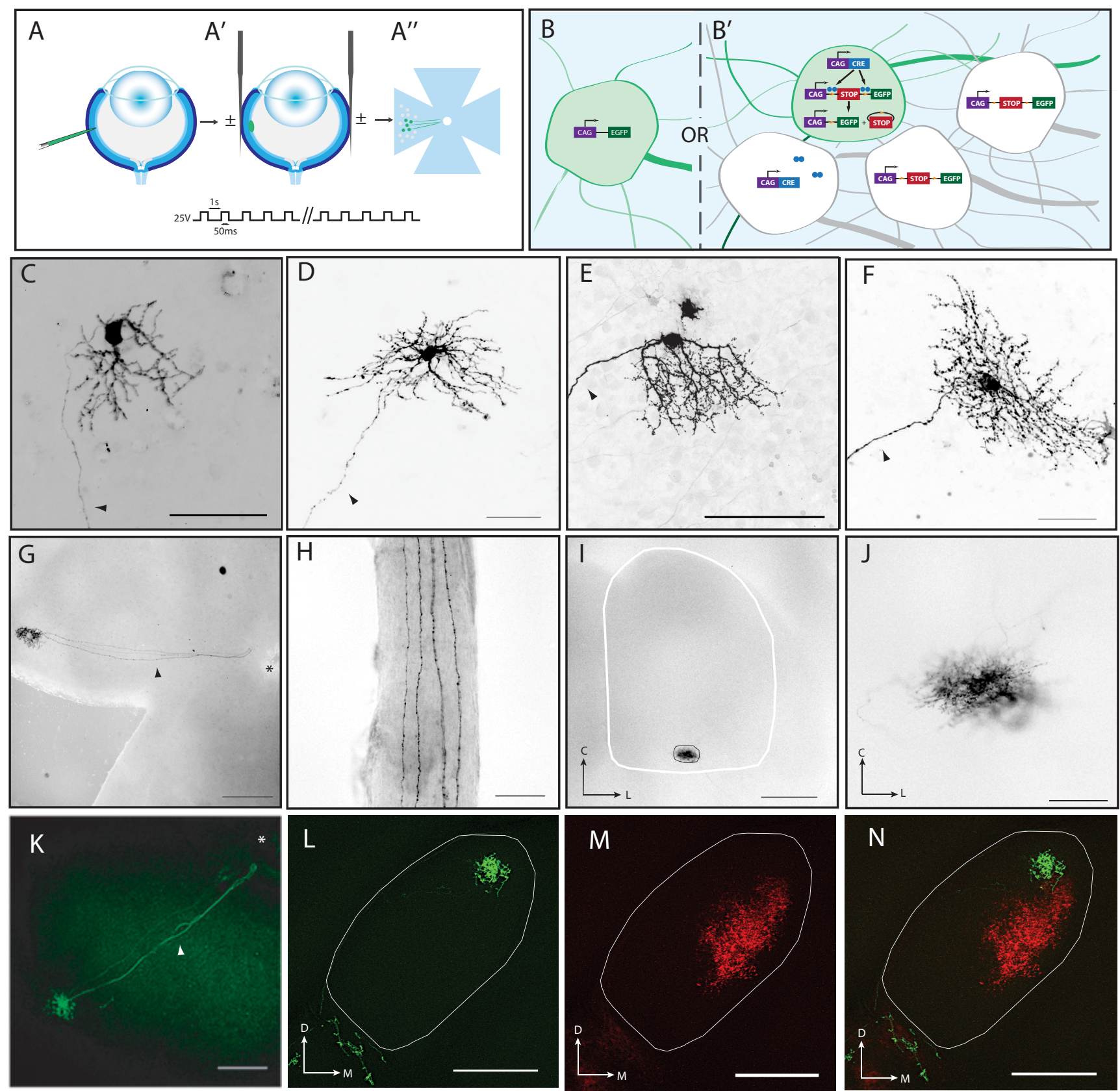

Figure 1. Retinotopy and eye-specific segregation examined using in vivo electroporation. Schematic of electroporation technique. $A$, A glass pipette containing plasmid DNA solution (depicted as green) was inserted into the retina (depicted as blue) through the retinal pigment epithelium (depicted as black) and beneath the scleral margin in mice ranging from P0 to P25. $\boldsymbol{A}^{\prime}$, A small injection ( 2.3-4.6nl) of plasmid DNA solution was made, and electrodes were placed over the injection site. Bipolar square pulses of 25 V, $50 \mathrm{~ms}$ duration and $1 \mathrm{~s}$ apart were applied. $A^{\prime \prime}$, After $1-10$ $\mathrm{d}$ electroporated retinas were dissected and screened for the presence of XFP-positive cells (green circles). Two strategies were used to label retinal cells with XFP. $\boldsymbol{B}$, First, retinal cells were electroporated with a pCAG - gapEGFP vector (CAG promoter, purple box; EGFP, green box) $\boldsymbol{B}^{\prime}$, Second, retinal cells were electroporated with a combination of two plasmids: pCAG-Cre and PCAG-flox-STOP-flox-gapXFP (Cre sequence, blue box; (re protein, blue circles; flox sequence, orange triangles; STOP sequence, red box). Only cells that were coelectroporated with both are able to express XFP. Both strategies $\left(\boldsymbol{B}, \boldsymbol{B}^{\prime}\right)$ led to strong labeling of cells, although the dual plasmid strategy $\left(\boldsymbol{B}^{\prime}\right)$ was more efficient for routinely labeling single RGCs. $\boldsymbol{C}-\boldsymbol{F}$, Examples of XFP-labeled single retinal ganglion cells (arrowhead pointing to axon) in a flat-mount retina at P2 (C), P4 (D), P8 (E), and P14 (F). G, A cluster of four electroporated temporal RGCs in a flat-mount retina at P8. The RGC axons (arrowhead) can be seen traversing toward the optic disc (asterisk). $\boldsymbol{H}$, Axons seen in $\mathbf{G}$ can be visualized and counted in the optic nerve. $\boldsymbol{I}$, The target zone (black outline) formed by the labeled $\mathrm{RGCS}$ (from $\mathbf{G}, \boldsymbol{H}$ ) on the anterior edge of the superior colliculus (whole-mount, white outline). $\boldsymbol{J}$, Target zone seen in $\boldsymbol{H}$ at a higher magnification. $\boldsymbol{K}$, Cluster of four electroporated RGCs in the temporal retina at P14 in a flat-mount retina. $\boldsymbol{L}$, Target zone formed by labeled RGCs in the dLGN (white outline). $\boldsymbol{M}$, Ipsilateral projections to the dLGN shown in $\boldsymbol{F}$ are labeled with CTB-Alexa Fluor 555. $\boldsymbol{N}$, Superimposition of EGFP $(\boldsymbol{L})$ and $(T B-A l e x a$ Fluor $555(\boldsymbol{M})$ labeling. The target zone formed by the contralateral projection (EGFP) is adjacent to and does not overlap with ipsilateral projections (CTB-Alexa Fluor 555). C, Caudal; L, lateral; D, dorsal; M, medial. Scale bars: C, $K-\boldsymbol{N}, 200 \mu \mathrm{m} ; \boldsymbol{E}, \boldsymbol{H}, \boldsymbol{J}, 100 \mu \mathrm{m} ; \mathbf{D}, \boldsymbol{F}, 50 \mu \mathrm{m} ; \mathbf{G}, \mathbf{I}, 500 \mu \mathrm{m}$.

Antibodies. Primary antibodies were as follows: anti-GFP antibody conjugated to Alexa Fluor 488 (1:250; catalog \#A21311; Invitrogen), rabbit polyclonal anti-GFP (1:500; catalog \#A-11122; Invitrogen), and rabbit polyclonal anti-Discosoma red (1:500; catalog \#632496; Clontech). Secondary antibodies were as follows: goat anti-rabbit conjugated to Alexa Fluor 488 antibody (1:300 or 1:500; catalog \#A-11008; Invitrogen)
Bulk anterograde labeling. Ipsilateral retinogeniculate axons were bulked labeled with Alexa Fluor 555 conjugated to cholera toxin subunit B (CTB) (C-34776; Invitrogen) $24 \mathrm{~h}$ before fixation. The tracer was diluted to $1 \mathrm{mg} / \mathrm{ml}$ in $0.9 \%$ saline. One to $2 \mu \mathrm{l}$ of tracer was injected into the left eye with a PV820 pneumatic picopump (World Precision Instruments). 


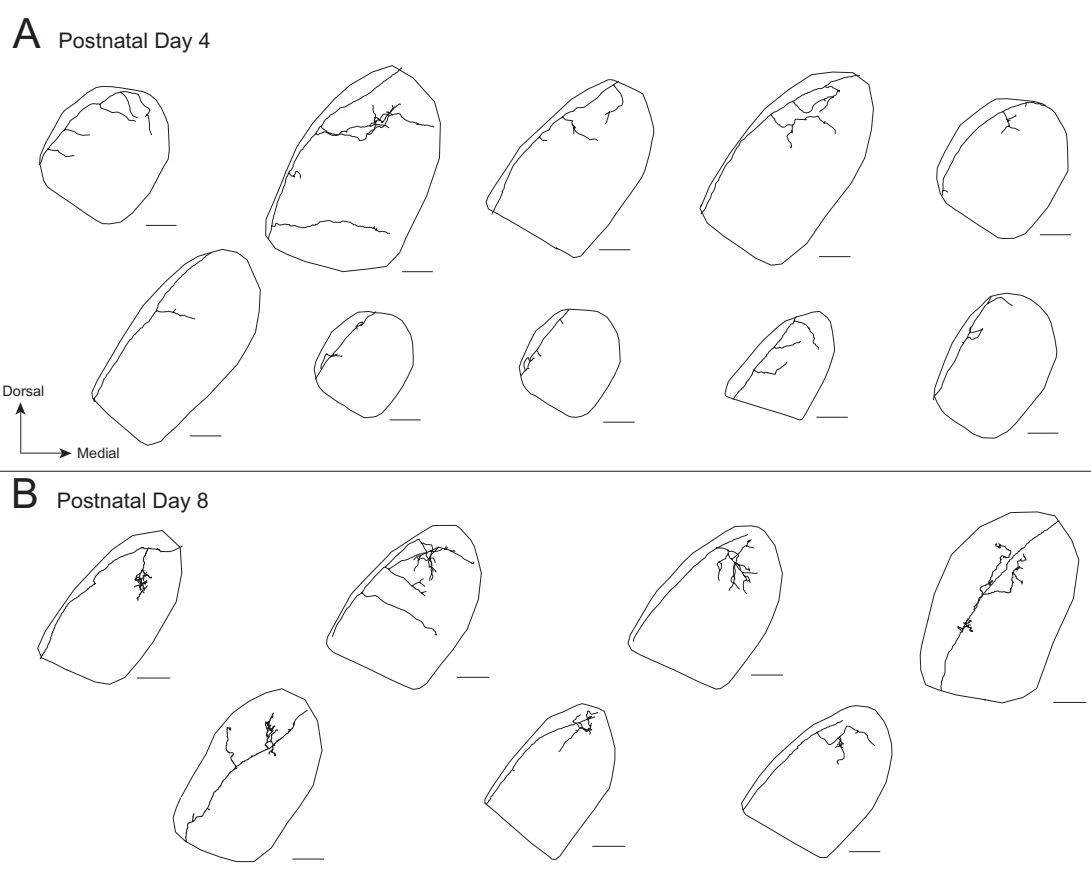

C Postnatal Day $14 / 15$
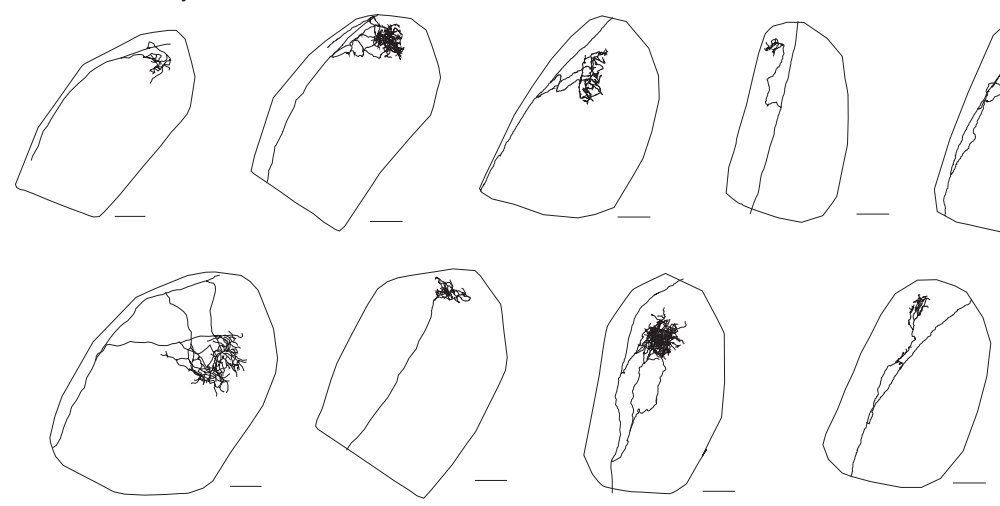

Figure 2. Single retinogeniculate axons in WT mice undergo elaboration of appropriately targeted collaterals and elimination of sparse inappropriate branches during the first 2 weeks after birth. Reconstructions of all single ventrotemporal RGC axon arbors in the dLGN (black outline, viewed in coronal plane) at $\mathrm{P} 4(\boldsymbol{A}), \mathrm{P} 8 / \mathrm{P} 9(\boldsymbol{B})$, and P14/P15 (C). Most arbors had multiple simple collaterals at $\mathrm{P} 4(\boldsymbol{A})$ that appear to converge and continue to increase in complexity at P8/P9 (B) and P14/P15 (C). Scale bars, $100 \mu \mathrm{m}$.

Image acquisition and quantitative analysis of retinogeniculate arbors. Images of retinogeniculate arbors were acquired using a confocal microscope and imaging system (Olympus Fluoview 300) with a $15 \mathrm{~mW}$ krypton/argon ion laser with a $25 \times$ multi-immersion objective [Carl Zeiss Plan-Neofluar; numerical aperture (NA) 0.80]. The emission filters were $540 / 30$ and $580 / 32 \mathrm{~nm}$. Three-dimensional (3-D) reconstructions of single RGC arbors were generated using Neurolucida (MicroBrightField). Reconstructions from consecutive brain sections were aligned by anatomical landmarks to fully reconstruct a single RGC arbor. The total arbor length and number of branch points is calculated using 3-D reconstructions of retinogeniculate arbors without the main axon trunk using NeuroExplorer (MicroBrightField). Average branch length is defined as the ratio of total arbor length to total number of branch points +1 . For calculating arbor area and density, a circular filter of $10 \mu \mathrm{m}$ diameter was used to blur the projection images of the 3-D reconstructions. Projection images on both the dorsomedial (coronal projection, $x-y$ axis) and dorsocaudal (sagittal projection, $x-z$ axis) axes were used to compute arbor area. Arbor area is defined as the sum of the area of all non-zero pixels. Arbor density is defined as the ratio of the sum of all non-zero pixel values to the total number of non-zero pixels. Area and mean density differences between age and genotype groups were not attributable to filter radius size chosen (data not shown).

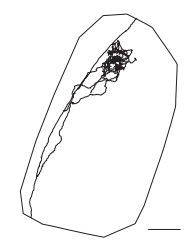

Image acquisition and quantitative analysis of retinocollicular arbors. Retinocollicular arbor images were acquired using an Ultima IV twophoton microscope (Prairie Technologies) with a Mai Tai HP laser (Deep See from Spectra Physics) at $920 \mathrm{~nm}$ with a $20 \times$ waterimmersion objective (Carl Zeiss; NA $=1.0$ ). 3 -D reconstructions of arbors were generated as described above. For all age groups, except $\mathrm{P} 2$, the total arbor length and number of branch points are calculated from the first branch point within the SC using NeuroExplorer (MicroBrightField). Because the number of nodes in P2 axons were very few to none, the total length is computed from the point of entry into the SC. Average branch length is calculated as described above. Average arbor area and density were computed as described above using 3-D reconstruction images that were rotated and collapsed to view the projections from the surface of the SC. The rostrocaudal (RC) and mediolateral (ML) extent was calculated from the point of entry into the SC.

To compare developmental trends between WT retinogeniculate and retinocollicular arbors, the mean values of total length, average branch length, number of branch points, arbor area, and density at P2, P4, P8/P9, and P14/P15 were normalized by the mean values at P14/P15 for the same structural parameters and are reported as percentages in supplemental Figure 5 (available at www.jneurosci.org as supplemental material).

\section{Results}

Labeling of various retinal cell types and visualization of retinotopic and eye-specific organization of retinofugal projections using in vivo electroporation We developed an in vivo electroporation protocol, which has become an attractive method for providing precise temporal and spatial control of gene or dye delivery in the retina (Haas et al., 2001; Dezawa et al., 2002; Matsuda and Cepko 2004; Huberman et al., 2005; Cerda et al., 2006; Garcia-Frigola et al., 2007; Rebsam et al., 2009), to express membrane targeted fluorescent proteins with the goal of visualizing RGC axon projections to the postnatal brain in mice (Fig. $1 A-A^{\prime \prime}$ ) (see Materials and Methods). Retinal cells were fluorescently labeled either by electroporating pCAG-gapEGFP plasmid (Fig. $1 B$ ) or a combination of pCAG-LNL-gapXFP and pCAG-Cre plasmids (XFP refers generically to either EGFP or mRFP1) (Fig. $1 B^{\prime}$ ) (see Materials and Methods). Electroporation of XFP expression vectors led to labeling of a range of retinal cell types, including retinal ganglion cells (Fig. $1 C-G, K$ ) (see Fig. 4A') (supplemental Figs. $1 A-D, 2 B$, available at www.jneurosci.org as supplemental material), horizontal cells (supplemental Fig. 1C,E, available at www.jneurosci.org as supplemental material), amacrine cells (supplemental Fig. $1 F-H$, available at www. jneurosci. org as supplemental material), and bipolar cells (data not shown). All processes, including both dendrites and axons, were clearly labeled, indicating that the XFP freely diffused throughout the cell. 

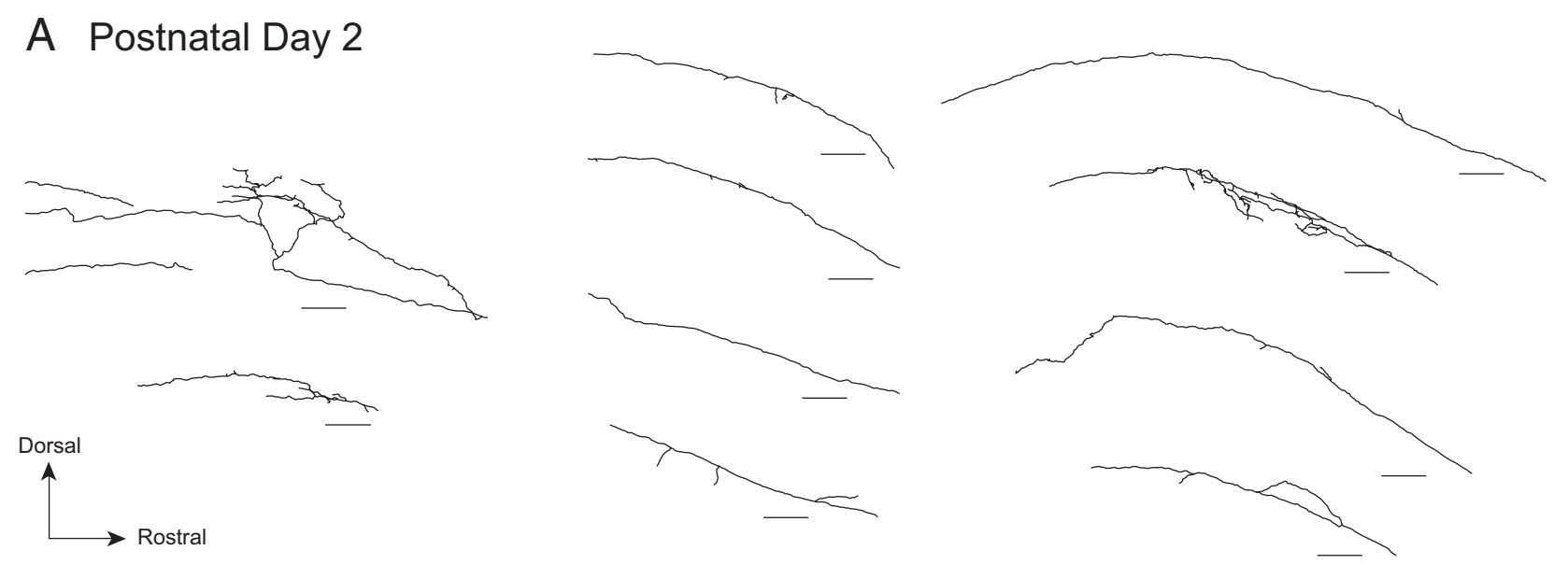

\section{B Postnatal Day 4}
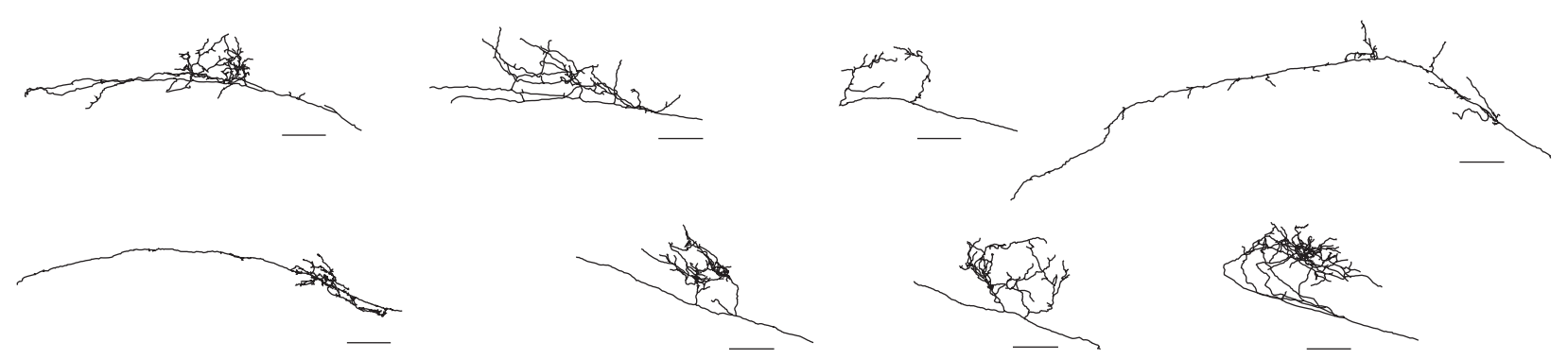

\section{Postnatal Day $8 / 9$}
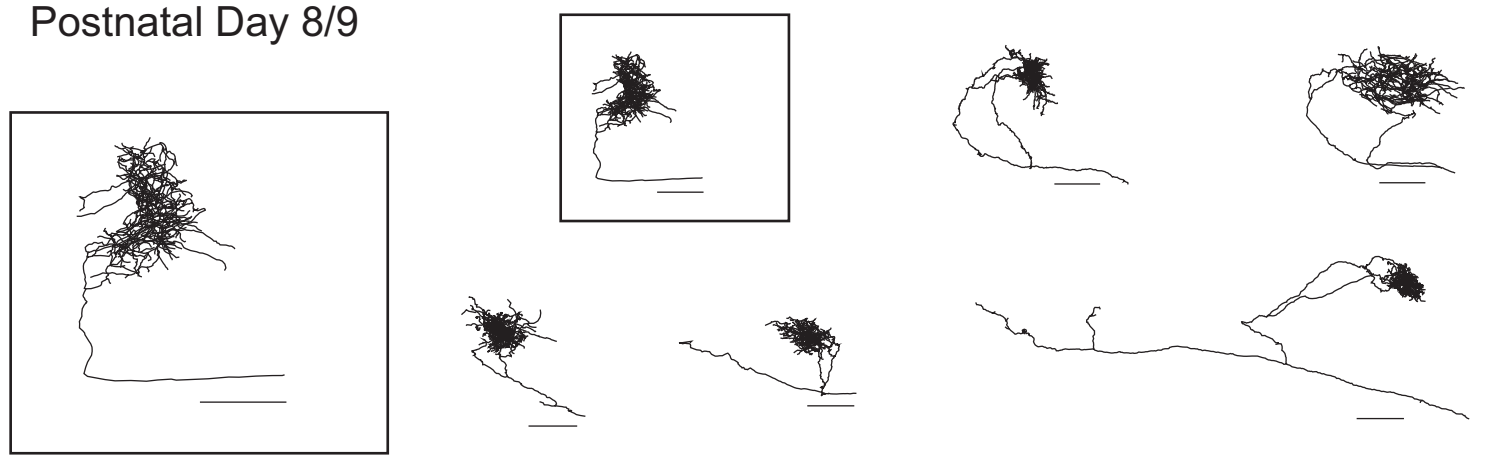

\section{Postnatal Day $14 / 15$}
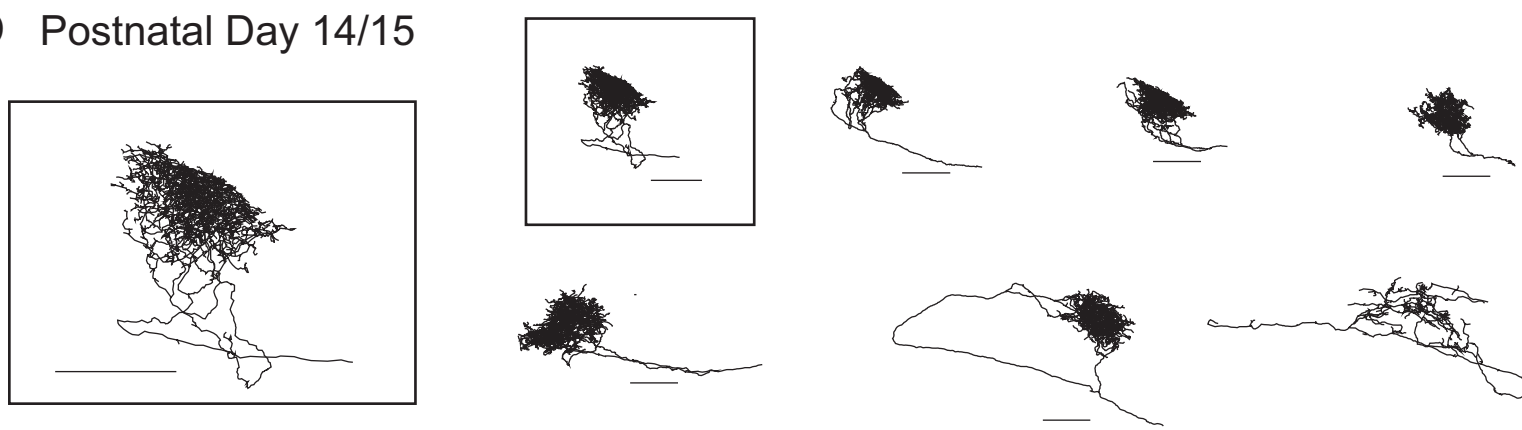

Figure 3. Development of single retinocollicular axons in WT mice reflects the transformation of the retinotopic map from a coarse state at P2 to a refined map at P14/P15. Reconstructions of all single temporal RGC axon arbors in the SC (sagittal sections) at P2 (A), P4 (B), P8/P9 (C), and P14/P15 (D). Temporal RGC axons initially have sparse collaterals and overshoot their appropriate termination in the anterior SC at P2 $(\boldsymbol{A})$. They form a coarse topographically appropriate arbor by $\mathrm{P} 4 / \mathrm{P5}(\boldsymbol{B})$ that continues to ramify within the confines of the termination region even during the second postnatal week $(\boldsymbol{C}, \boldsymbol{D})$. Scale bars, $100 \mu \mathrm{m}$. For illustration, boxed arbors in $\boldsymbol{C}$ and $\boldsymbol{D}$ are of the same axon at different spatial scales. 


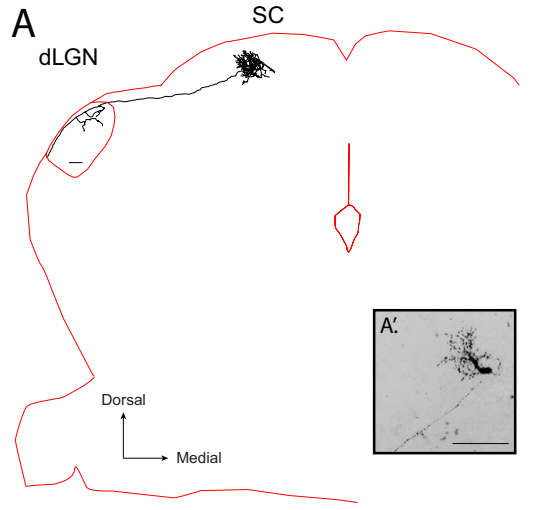

B
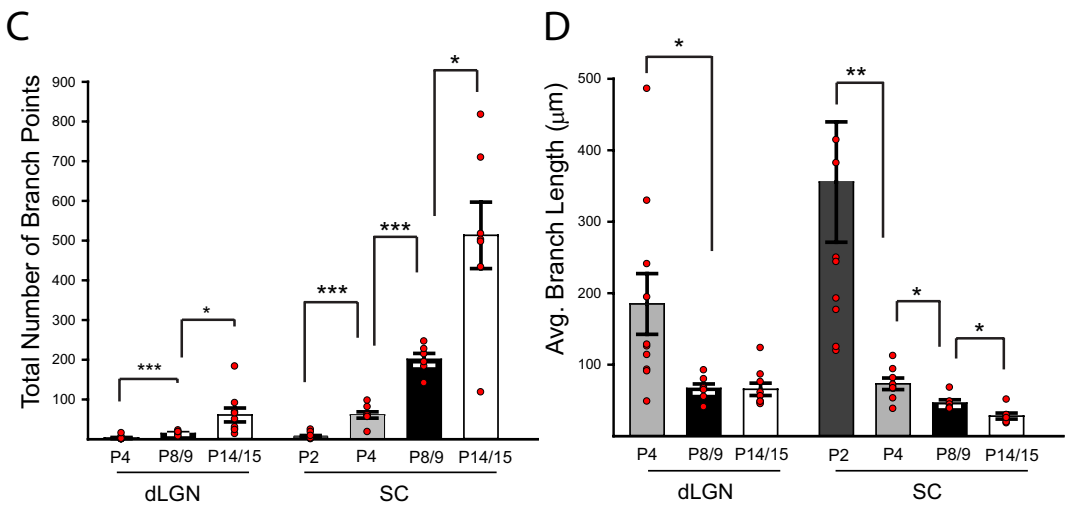

E

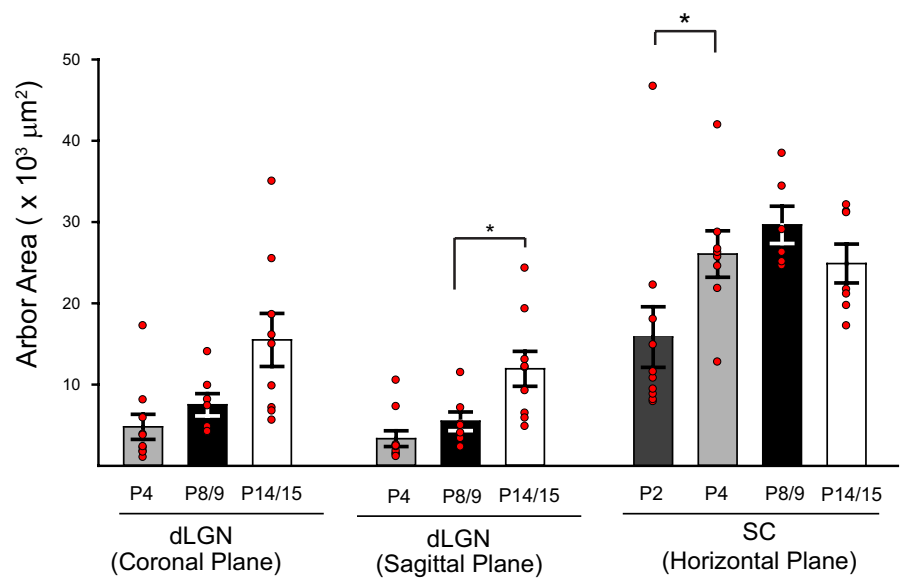

$\mathrm{F}$

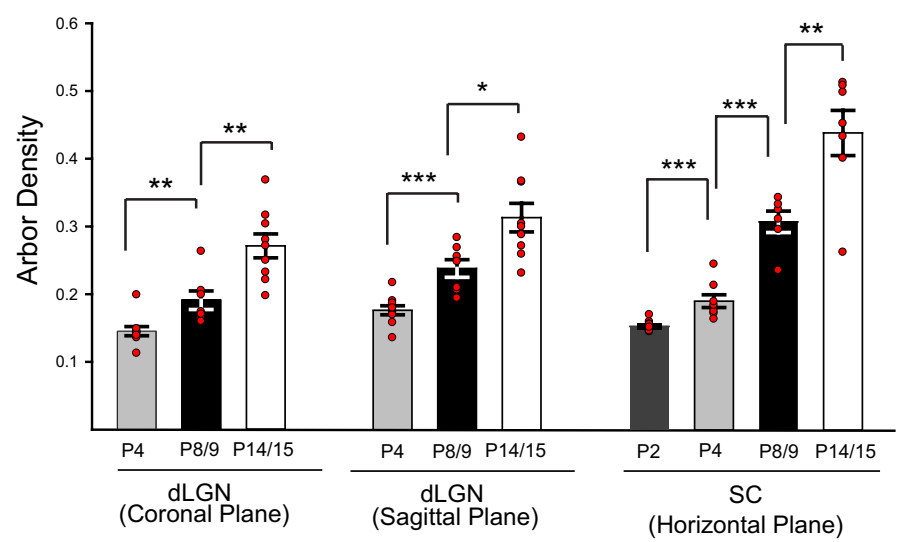

Figure 4. Comparison of the maturation of single retinogeniculate and retinocollicular axons suggests a delay in arbor development in the dLGN versus SC. $\boldsymbol{A}$, Example of a single temporal RGC (inset, $\boldsymbol{A}^{\prime}$ ) projecting to and arborizing in both the dLGN and SC at P4. Section outline (red) created by superimposing five consecutive coronal sections through which the RGC axon traversed. Quantification of total arbor length $(\boldsymbol{B})$, total number of branch points $(\boldsymbol{C})$, average branch length $(\boldsymbol{D})$, arbor area $(\boldsymbol{E})$, arbor density
We tested whether we could visualize retinotopy and eye-specific segregation in the retinofugal pathway by transfecting RGCs with GFP-encoding plasmids via electroporation. Temporal RGCs electroporated with EGFP at $\mathrm{P} 5$ formed a small termination zone in the anterior SC by P8 (Fig. $1 G-J)$, reflecting the nearly complete refinement of retinocollicular projections at the end of the first postnatal week (McLaughlin et al., 2003). Similarly, ventrotemporal retinogeniculate projections visualized via electroporation revealed that GFP-labeled axons were localized to the dorsal portion of the contralateral dLGN adjacent to the ipsilateral region (Fig. $1 K-N$ ), reflecting the completion of eye-specific layering in the dLGN at eye opening (approximately P14) (Huberman et al., 2008a). These results demonstrate that labeling a small population of RGCs by in vivo electroporation of expression vectors encoding fluorescent proteins reproduces the major features of axonal projection patterns observed previously using other methods (McLaughlin et al., 2003; Huberman et al., 2008a), and indicates that our method did not interfere with the refinement of RGC axon projections to the SC and dLGN.

\section{Development of single contralateral RGC axon arbors in the dLGN}

To visualize the development of single contralateral RGCs arbors in the dLGN, we used the electroporation protocol to label single ventrotemporal RGCs at P2-P3, P6-P8, and P12-P13 with pCAG-gapEGFP or with pCAG-Cre and pCAG-LNL-gapEGFP plasmids. Forty-eight to $72 \mathrm{~h}$ later, wholemount retinas and coronal brain sections were immunostained for GFP (supplemental Fig. 2G-I, available at www.jneurosci.org as supplemental material). At P4, contralaterally projecting single RGC axons traversed the lateral border of the dLGN and typically had multiple sparse collaterals branching from different positions along the lateral border (Fig. 2A) (supplemental Fig. 3A, available at www.jneurosci.org as supplemental material). At P8/P9, RGC axon collaterals were increasingly complex, forming a sparse arbor (seven of seven) in the topographically appropriate dorsal half of the dLGN (Fig. 2B) (supplemental Fig. 3B,

\section{$\leftarrow$}

(F) of single RGC axon arbors at P2 (dark gray), P4 (light gray), P8/P9 (black), and P14/P15 (white) in the dLGN and SC. Bars represent mean, and red circles are individual data points. Error bars indicate SEM. Scale bars, $100 \mu \mathrm{m} .{ }^{*} p<0.05 ;{ }^{* *} p<$ $0.01 ; * * * 00.001$. 
Table 1. Quantification of structural parameters based on 3-D reconstructions of single WT RGC arbors in the dLGN in WT and $\beta 2^{-/-}$mice at multiple developmental time points

\begin{tabular}{|c|c|c|c|c|c|c|}
\hline & & P4 & & P8/P9 & & P14/P15 \\
\hline Number of reconstructed arbors & $\begin{array}{l}\text { WT } \\
\beta 2^{-1-}\end{array}$ & $\begin{array}{r}10 \\
9\end{array}$ & & $\begin{array}{l}7 \\
6\end{array}$ & & $\begin{array}{l}9 \\
6\end{array}$ \\
\hline Total length $(\mu \mathrm{m})$ & $\begin{array}{l}\text { WT } \\
\beta 2^{-\prime-}\end{array}$ & $\begin{array}{l}498.70 \pm 186.30 \\
689.16 \pm 183.51\end{array}$ & $\begin{array}{l}\# \\
* *\end{array}$ & $\begin{array}{r}984.36 \pm 154.85 \\
2216.63 \pm 467.06\end{array}$ & * & $\begin{array}{l}3627.01 \pm 842.37 \\
4255.63 \pm 1101.23\end{array}$ \\
\hline Number of branch points & $\begin{array}{l}\text { WT } \\
\beta 2^{-1-}\end{array}$ & $\begin{array}{l}2.70 \pm 1.50 \\
7.11 \pm 3.15\end{array}$ & $* * *$ & $\begin{array}{l}14.14 \pm 2.24 \\
16.17 \pm 4.47\end{array}$ & * & $\begin{array}{l}60.89 \pm 17.47 \\
68.50 \pm 23.30\end{array}$ \\
\hline Average branch length $(\mu \mathrm{m})$ & $\begin{array}{l}\text { WT } \\
\beta 2^{-\prime-}\end{array}$ & $\begin{array}{l}184.91 \pm 42.50 \\
128.86 \pm 26.65\end{array}$ & * & $\begin{array}{c}66.64 \pm 6.25 \\
136.10^{* *} \pm 17.35\end{array}$ & ** & $\begin{array}{l}65.47 \pm 8.65 \\
68.25 \pm 8.37\end{array}$ \\
\hline Arbor area $\left(\mu \mathrm{m}^{2}\right)$ (coronal plane) & $\begin{array}{l}\text { WT } \\
\beta 2^{-1-}\end{array}$ & $\begin{array}{l}4787.21 \pm 1542.14 \\
5041.15 \pm 1190.20\end{array}$ & ** & $\begin{array}{c}7507.60 \pm 1367.55 \\
\text { \#\#\# } \\
12,374.90 \pm 2367.78\end{array}$ & $\# \#$ & $\begin{array}{l}15,491.57 \pm 3263.96 \\
19,417.90 \pm 3995.77\end{array}$ \\
\hline Arbor density (coronal plane) & $\begin{array}{l}\text { WT } \\
\beta 2^{-1-}\end{array}$ & $\begin{array}{l}0.15 \pm 0.01 \\
0.18 \pm 0.01\end{array}$ & $\begin{array}{l}* * \\
* *\end{array}$ & $\begin{array}{l}0.19 \pm 0.01 \\
\# \\
0.24 \pm 0.02\end{array}$ & $* *$ & $\begin{array}{l}0.27 \pm 0.02 \\
0.26 \pm 0.02\end{array}$ \\
\hline Arbor area $\left(\mu \mathrm{m}^{2}\right)$ (sagittal plane) & $\begin{array}{l}\text { WT } \\
\beta 2^{-/-}\end{array}$ & $\begin{array}{l}3551.08 \pm 1215.81 \\
5886.62 \pm 1353.09\end{array}$ & $* *$ & $\begin{array}{r}5703.62 \underset{* *}{*} 1331.42 \\
14,373.75 \pm 1895.13\end{array}$ & * & $\begin{array}{c}12,673.87 \pm 2282.74 \\
21,311.53 \pm 4511.34\end{array}$ \\
\hline Arbor density (sagittal plane) & $\begin{array}{l}\text { WT } \\
\beta 2^{-1-}\end{array}$ & $\begin{array}{l}0.18 \pm 0.01 \\
0.18 \pm 0.01\end{array}$ & $* * *$ & $\begin{array}{l}0.25 \pm 0.01 \\
0.22 \pm 0.02\end{array}$ & * & $\begin{array}{l}0.32 \pm 0.02 \\
\# \\
0.26 \pm 0.02\end{array}$ \\
\hline
\end{tabular}

Mean \pm SEM of various structural parameters for WT and $\beta 2^{-\prime-}$ retinogeniculate arbors at different ages. Asterisks between columns and rows identify statistical difference between ages and genotypes: ${ }^{*} p<0.05 ;{ }^{* *} p<0.01 ;{ }^{* * *} p<$ 0.001 . For completion, all $p$ values $<0.1$ are reported. Number signs indicate $p$ values for indicated age and genotype groups: $\#=0.07 ; \# p=0.06 ; " \# \#=0.09$.

Table 2. Quantification of structural parameters based on 3-D reconstructions of single retinocollicular arbors in WT and $\beta 2^{-1-}$ mice at multiple developmental stages

\begin{tabular}{|c|c|c|c|c|c|c|c|c|}
\hline & & P2 & & P4 & & P8/P9 & & P14/P15 \\
\hline \multirow[t]{2}{*}{ Number of reconstructed arbors } & WT & 10 & & 8 & & 6 & & 7 \\
\hline & $\beta 2^{-1-}$ & 6 & & 8 & & 7 & & 6 \\
\hline \multirow[t]{2}{*}{ Total length $(\mu \mathrm{m})$} & WT & $1690.82 \pm 394.05$ & $* *$ & $4307.41 \pm 585.95$ & $* * *$ & $9127.77 \pm 707.42$ & $\#$ & $12,593.99 \pm 1475.64$ \\
\hline & $\beta 2^{-/-}$ & $1445.83 \pm 362.03$ & * & $4167.13 \pm 731.94$ & & $6939.13 \pm 1541.13$ & ** & $18,402.43 \stackrel{*}{ \pm} 2285.72$ \\
\hline \multirow[t]{2}{*}{ Number of branch points } & WT & $6.70 \pm 2.52$ & $* * *$ & $60.75 \pm 8.03$ & $* * *$ & $200.83 \pm 15.10$ & * & $513.29 \pm 83.62$ \\
\hline & $\beta 2^{-1-}$ & $6.67 \pm 2.81$ & * & $37.00 \pm 9.08$ & & $69.71 \pm 25.32$ & $* *$ & $411.50 \pm 91.02$ \\
\hline \multirow[t]{2}{*}{ Average branch length ( $\mu \mathrm{m})$} & WT & $355.40 \pm 84.20$ & $* *$ & $73.14 \pm 8.13$ & * & $46.21 \pm 4.58$ & * & $27.98 \pm 4.18$ \\
\hline & $\beta 2^{-1-}$ & $279.42 \pm 61.94$ & $*$ & $137.22 \pm 30.27$ & & $198.50 \pm 94.73$ & & $51.93 \pm 7.43^{*}$ \\
\hline \multirow[t]{2}{*}{ Arbor density } & WT & $0.15 \pm 0.002$ & $* * *$ & $0.19 \pm 0.01$ & $* * *$ & $0.31 \pm 0.02$ & ** & $0.44 \pm 0.03$ \\
\hline & $\beta 2^{-1-}$ & $0.15 \pm 0.002$ & $* *$ & $0.18 \pm 0.01$ & & $0.18^{* * *} \pm 0.01$ & $*$ & $0.23 \pm 0.01$ \\
\hline \multirow[t]{2}{*}{ Arbor area $\left(\mu \mathrm{m}^{2}\right)$} & WT & $15,852.12 \pm 3733.34$ & * & $26,060.29 \pm 2857.49$ & & $29,653.36 \pm 2293.9^{\S}$ & & $24,899.54 \pm 2398.29^{\# \#}$ \\
\hline & $\beta 2^{-/-}$ & $13,815.08 \pm 3216.95$ & * & $32,376.74 \pm 5051.2$ & & $51,424.19 \pm 10203.94$ & * & $89,803.98^{* * *} \pm 9360.86$ \\
\hline \multirow[t]{2}{*}{ Rostrocaudal axis ( $\mu \mathrm{m})$} & WT & $798.49 \pm 85.50$ & & $732.42 \pm 164.75$ & & $421.28 \pm 132.18^{\text {执 }}$ & & $428.48 \pm 79.90^{\dagger \dagger}$ \\
\hline & $\beta 2^{-1-}$ & $653.53 \pm 106.11$ & * & $1005.67 \pm 150.69$ & & $885.60^{* * *} \pm 70.69^{\S \S}$ & & $961.05^{* * *} \pm 139.96$ \\
\hline \multirow[t]{2}{*}{ Mediolateral axis $(\mu \mathrm{m})$} & & $185.36 \pm 32.37$ & & $276.28 \pm 55.52$ & & $304.60 \pm 20.73$ & * & $230.24 \pm 26.55$ \\
\hline & $\beta 2^{-1-}$ & $256.07 \pm 43.60$ & & $322.79 \pm 58.92$ & & $429.16 \pm 130.39$ & & $392.91 \pm 83.60$ \\
\hline
\end{tabular}

Mean \pm SEM for all measurements for WT and $\beta 2^{-1-}$ retinocollicular arbors at different ages. Asterisks between columns and rows identify statistically significant differences: ${ }^{*} p<0.05 ; * * p<0.01 ; * * * p<0.001$. For completion, all $p$ values $<0.1$ are reported. The following symbols indicate $p$ values for age and genotype groups indicated: ${ }^{\#} p=0.07$ between $\mathrm{P} 8 / \mathrm{P} 9$ and P14/P15 WT and ${ }^{\# \#} p=0.07$ between $\mathrm{P} 2$ and $\mathrm{P} 14 / \mathrm{P} 15 \mathrm{WT} ;{ }^{\dagger} p=0.07$ between $\mathrm{P} 4 \mathrm{WT}$ and $\beta 2-/-$

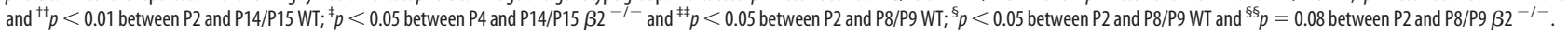

available at www.jneurosci.org as supplemental material). By P14/ P15, RGC arbors were still more complex and fully innervated their target area forming a dense termination zone (Fig. 2C) (supplemental Fig. 3C, available at www.jneurosci.org as supplemental material).

To quantify the changes in retinal arbors with development, we computed five structural parameters for each single arbor in the dLGN (see Fig. $4 B-F$ ) (Table 1): (1) total arbor length, which we use to examine arbor growth; (2) total number of branch points, which reflects arbor maturation; (3) average branch length, which is a measure for arbor refinement; (4) mean arbor area, which is a measure of the territory occupied by arbors; and
(5) arbor density, which is a measure of axon arbor overlap (for a detailed description of these quantities, see Materials and Methods and Antonini and Stryker, 1993). Between P4 and P14/P15, contralateral retinogeniculate arbors elongated significantly and became more complex as evidenced by increases in the total arbor length, number of branch points, arbor density and area, and decrease in average branch length during the first postnatal week (see Fig. 4) (Table 1). These measurements suggest that RGC axon arbors grow continuously in the dLGN during the first 2 postnatal weeks but become progressively more restricted, complex, and dense. These observations are consistent with a model in which eye-specific segregation occurs as a consequence of in- 

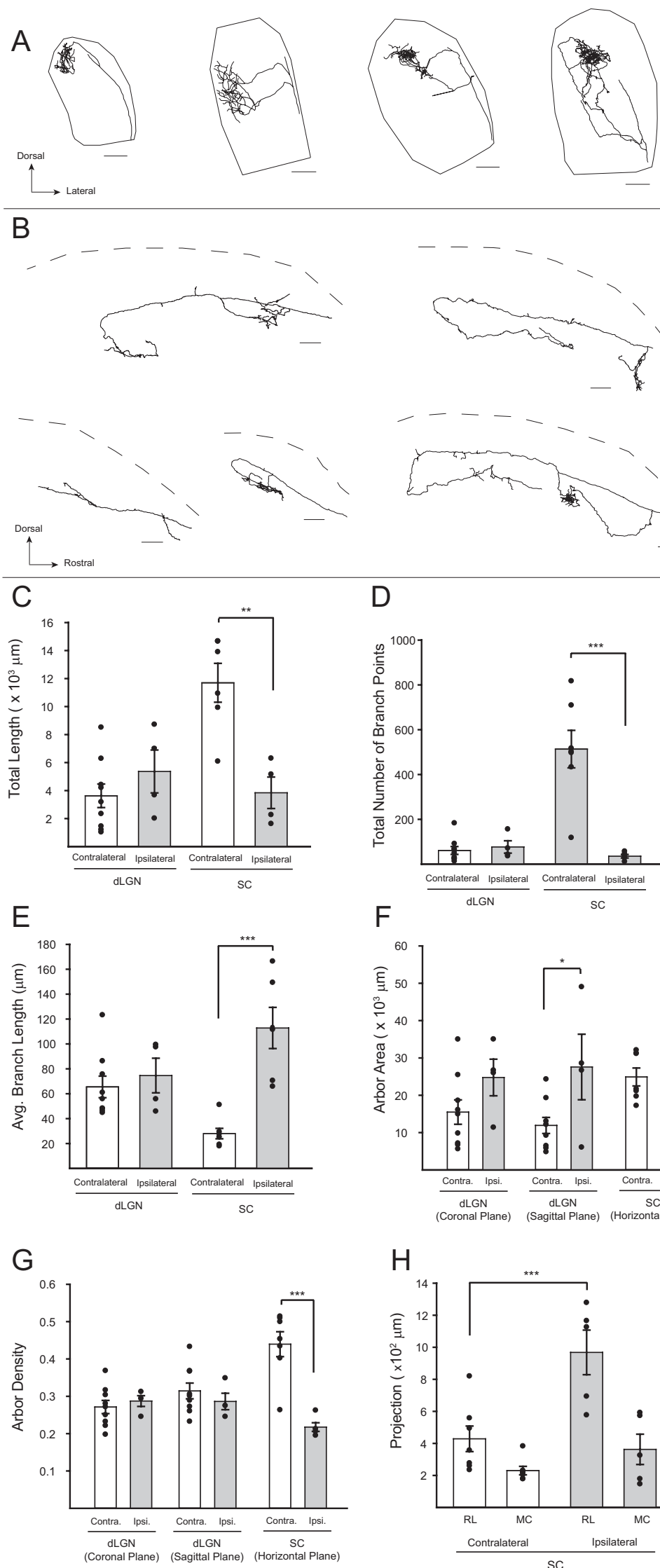
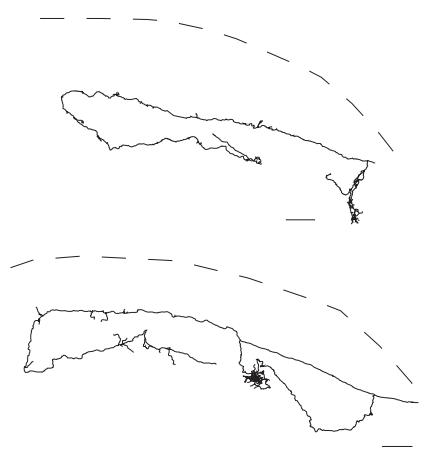

D

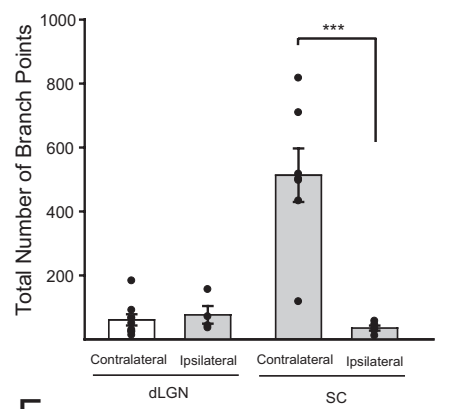

$\mathrm{F}$
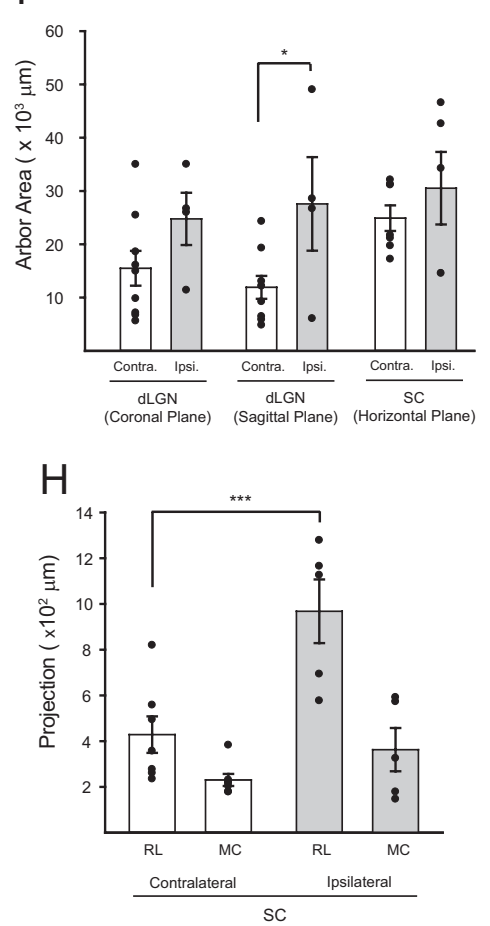

Figure 5. Analysis of single ipsilateral retinogeniculate and retinocollicular axonal arbors in WT mice at P14/P15 reveals structural differences between binocular inputs in the SC versus $\mathrm{dLGN}$. Reconstructions of single ipsilateral RGC projections in the $\operatorname{dLGN}(\boldsymbol{A}$, black outline) and SC ( $\boldsymbol{B}$, dashed lines represent partial SC surface) at P14/P15. Quantitative comparison of total arbor

creased arborization of correctly targeted axons in concert with the elimination of inappropriate sparse collateral branches (Sretavan and Shatz 1986; Hahm et al., 1999; Snider et al., 1999).

\section{Development of single contralateral RGC axon arbors in the SC}

We next visualized single contralateral RGC axonal arbors in the SC during the first 2 postnatal weeks, when the retinocollicular map undergoes significant structural changes. RGCs in the temporal retina of $\mathrm{P} 0-\mathrm{P} 1, \mathrm{P} 2$, or $\mathrm{P} 4-\mathrm{P} 6$ mice were coelectroporated with pCAG-Cre and pCAG-LNL-gapXFP plasmids $(\sim 2.3 \mathrm{nl}$ injection). Electroporated mice were killed at $\mathrm{P} 2, \mathrm{P} 4$, and $\mathrm{P} 8 / \mathrm{P} 9$ or $\mathrm{P} 14 / \mathrm{P} 15$, respectively. Whole-mount retinas and sagittal brain sections were immunostained for XFP (supplemental Fig. 2A-F, available at www.jneurosci.org as supplemental material). To quantify the changes in contralateral retinocollicular arbors, we computed the same structural parameters that were quantified for single arbors in the dLGN, and, in addition, we measured axon arbor extent along the $\mathrm{RC}$ and $\mathrm{ML}$ axis in the SC (see Fig. 9) (Table 2).

Contralateral retinocollicular axon arbors undergo significant structural refinement during the first 2 postnatal weeks. At $\mathrm{P} 2$, all temporal RGC axons overshot their correct termination zone on the anterior edge of the SC, and a majority of RGCs (7 of 10) had very few (less than or equal to four) and short collaterals along the length of the axon (Fig. $3 A$ ) (supplemental Fig. $4 A$, available at www.jneurosci.org as supplemental material). Over the course of the first 2 weeks, the RC but not the ML extent of RGC arbors decreased (see Fig. 9F) (Table 2). Between P2 and $\mathrm{P} 4$, some collaterals were eliminated but branches that were maintained continued to elaborate and converged to form a single termination zone in the anterior half of the SC, as is evidence by the changes in total length, number of branch points, and density of the arbors (see Fig. 9) (Table 2). However, at P4, most axons (six of eight) still maintained very simple over-

\section{$\leftarrow$}

length $(\boldsymbol{C})$, total number of branch points $(\boldsymbol{D})$, average branch length $(\boldsymbol{E})$, mean arbor area $(\boldsymbol{F})$ of projections of 3-D arbor reconstructions. $\mathbf{G}$, Average density of ipsilateral (gray bars) and contralateral (white bars) RGC arbor reconstructions in the $\mathrm{dLGN}$ and $\mathrm{SC} . \boldsymbol{H}$, Rostrocaudal and mediolateral projection extent of single contralateral and ipsilateral axon arbors in the SC. Bars represent mean, and red circles are individual data points. Error bars indicate SEM. Scale bars, $100 \mu \mathrm{m} .{ }^{*} p<$ $0.05 ;{ }^{* *} p<0.01 ;{ }^{* * *} p<0.001$. 
Table 3. Quantification of structural parameters based on 3-D reconstructions of single contralateral and ipsilateral WT RGC arbors in the dLGN at multiple developmenta time points

\begin{tabular}{|c|c|c|c|c|c|c|}
\hline & & P4 & & P8/P9 & & P14/P15 \\
\hline Number of reconstructed arbors & $\begin{array}{l}\text { Contralateral } \\
\text { Ipsilateral }\end{array}$ & $\begin{array}{r}10 \\
6\end{array}$ & & $\begin{array}{l}7 \\
4\end{array}$ & & $\begin{array}{l}9 \\
4\end{array}$ \\
\hline Total length $(\mu \mathrm{m})$ & $\begin{array}{l}\text { Contralateral } \\
\text { Ipsilateral }\end{array}$ & $\begin{array}{l}498.70 \pm 186.30 \\
852.93 \pm 157.78\end{array}$ & $\begin{array}{l}\# \\
*\end{array}$ & $\begin{array}{c}984.36 \pm 154.85 \\
5821.28 \pm 2433.61\end{array}$ & * & $\begin{array}{l}3627.01 \pm 842.37 \\
5364.93 \pm 1533.14\end{array}$ \\
\hline Number of branch points & $\begin{array}{l}\text { Contralateral } \\
\text { Ipsilateral }\end{array}$ & $\begin{array}{l}2.70 \pm 1.50 \\
7.67 \pm 1.31\end{array}$ & $\begin{array}{l}* * * \\
*\end{array}$ & $\begin{array}{c}14.14 \pm 2.24 \\
117.75^{*} \pm 58.79\end{array}$ & * & $\begin{array}{l}60.89 \pm 17.47 \\
76.50 \pm 13.92\end{array}$ \\
\hline Average branch length $(\mu \mathrm{m})$ & $\begin{array}{l}\text { Contralateral } \\
\text { Ipsilateral }\end{array}$ & $\begin{array}{c}184.91 \pm 42.50 \\
95.85 \pm 8.91\end{array}$ & * & $\begin{array}{l}66.64 \pm 6.25 \\
72.37 \pm 16.49\end{array}$ & & $\begin{array}{l}65.47 \pm 8.65 \\
74.62 \pm 13.92\end{array}$ \\
\hline Arbor area $\left(\mu \mathrm{m}^{2}\right)$ (coronal plane) & $\begin{array}{l}\text { Contralateral } \\
\text { Ipsilateral }\end{array}$ & $\begin{array}{l}4787.21 \pm 1542.14 \\
7606.09 \pm 1503.82\end{array}$ & & $\begin{array}{r}7507.60 \pm 1367.55 \\
20,366.27 \pm 5039.91\end{array}$ & \#\# & $\begin{array}{l}15,491.57 \pm 3263.96 \\
24,767.69 \pm 4905.53\end{array}$ \\
\hline Arbor density (coronal plane) & $\begin{array}{l}\text { Contralateral } \\
\text { Ipsilateral }\end{array}$ & $\begin{array}{l}0.15 \pm 0.01 \\
0.20 \pm 0.01\end{array}$ & ** & $\begin{array}{l}0.19 \pm 0.01 \\
0.30^{*} \pm 0.05\end{array}$ & ** & $\begin{array}{l}0.27 \pm 0.02 \\
0.29 \pm 0.01\end{array}$ \\
\hline Arbor area $\left(\mu \mathrm{m}^{2}\right)$ (sagittal plane) & $\begin{array}{l}\text { Contralateral } \\
\text { Ipsilateral }\end{array}$ & $\begin{aligned} 3551.08 \pm 1215.81 \\
\text { \# } \\
6282.46 \pm 1066.68\end{aligned}$ & * & $\begin{array}{r}5703.62 \pm 1331.42 \\
* 20,381.20 \pm 1066.68\end{array}$ & * & $\begin{array}{l}12,673.87 \pm 2282.74 \\
27,575.87 \pm 8775.13\end{array}$ \\
\hline Arbor density (sagittal plane) & $\begin{array}{l}\text { Contralateral } \\
\text { Ipsilateral }\end{array}$ & $\begin{array}{l}0.18 \underset{* *}{ \pm} 0.01 \\
0.22 \pm 0.01\end{array}$ & *** & $\begin{array}{l}0.25 \pm 0.01 \\
\# \# \\
0.31 \pm 0.04\end{array}$ & * & $\begin{array}{l}0.32 \pm 0.02 \\
* .29 \pm 0.02\end{array}$ \\
\hline
\end{tabular}

Mean \pm SEM of various structural parameters for WT contralateral and ipsilateral retinogeniculate arbors at different ages. Asterisks between columns and rows identify statistically significant difference between ages and genotypes: ${ }^{*} p<$ $0.05 ;{ }^{* *} p<0.01 ;{ }^{* *} p<0.001$. For completion, all $p$ values $<0.1$ are reported. ${ }^{\#} p=0.07 ;{ }^{\# \#} p=0.06$.

shoots (Fig. 3B) (supplemental Fig. 4B, available at www. jneurosci.org as supplemental material). By P8/P9, the axon collaterals had ramified in their topographically appropriate location to form a dense and spatially restricted arbor (Fig. 3C) (supplemental Fig. 4C, available at www.jneurosci.org as supplemental material). This is reflected in significant increases in the total length, number of branch points and arbor density, and a decrease in average branch length between P4 and P8/P9 (see Fig. 9) (Table 2). RGC arbors did not undergo further refinement during the second postnatal week, but they continued to ramify within the preexisting termination zone as evidenced by a decrease in average branch length and increases in the total number of branch points and density (Fig. 3D; Table 2) (supplemental Fig. 4D, available at www.jneurosci.org as supplemental material) (see Fig. 9). Although some axons (3 of 13) maintained their overshoot after P4, these overshooting segments had little to no branching (Fig. 3C,D) (supplemental Fig. 4C,D, available at www.jneurosci.org as supplemental material).

In summary, analysis of single retinocollicular axons suggests that contralateral RGC arbors in the SC undergo two distinct but overlapping phases of structural refinement during map development. During the first postnatal week, RGC arbors eliminate and retract inappropriate but sparse branches and overshoots and dramatically elaborate topographically appropriate branches within a restricted area of the initially broad but sparse arbor. During the second postnatal week, RGC arbors undergo further elaboration and refinement only within the confines of their preexisting terminal arbor.

\section{Comparison of contralateral RGC axon arbor development in the SC and dLGN}

A direct comparison of WT contralateral RGC arbor development in the SC and dLGN reveals several properties that are common and several that are distinct (Fig. 4) (supplemental Fig. 5, available at www.jneurosci.org as supplemental material). Contralateral arbors in both the SC and dLGN undergo concurrent elimination of inappropriately directed branches as well as the elaboration of arbors within a confined region of the termination zone. RGC arbors in both targets also form collaterals at multiple points along the length of the axon that then appear to converge to form a single confined termination zone that becomes progressively denser and spatially restricted over the course of development.

Despite the general similarities in the developmental profile of RGC axon arbors in the SC and dLGN, there are clear differences. In particular, the developmental elaboration of RGC arbors in the dLGN appears delayed by nearly 1 week relative to the SC. For example, RGC axon arbors in the SC are grossly complete as early as $\mathrm{P} 4$ (Fig. 3B) (supplemental Fig. $4 B$, available at www.jneurosci. org

supplemental material), whereas arbors in the dLGN remain very sparse and simple at this age [compare reconstructions in Fig. $2 \mathrm{~A}$ and supplemental Fig. $3 A$ (available at www.jneurosci.org as supplemental material) with Fig. $3 B$ and supplemental Fig. $4 B$ (available at www.jneurosci.org as supplemental material)]. Analysis of growth trends shows a sharp increase in the total length and number of branches during the second postnatal week for contralateral retinogeniculate axons, whereas these parameters increase more dramatically during the first postnatal week for retinocollicular arbors (supplemental Fig. 5, available at www. jneurosci.org as supplemental material). In addition, at the end of the second postnatal week, RGC arbor structures in the SC are more homogenous in appearance and achieve a degree of complexity greater than that found in the dLGN (Figs. 2C, 3D). The difference in the timing of RGC arbor maturation suggests the existence of target-derived factors that strongly influence axon arbor development (Jhaveri et al., 1991).

\section{Maturation and comparison of ipsilateral RGC axon arbors in the dLGN and SC}

We visualized and quantified the maturation of single ipsilateral RGCs arbors in the dLGN and SC in the same manner as described above for contralateral RGC axon arbors. In general, ipsilateral RGC arbors in the dLGN displayed a similar devel- 
A Postnatal Day 4
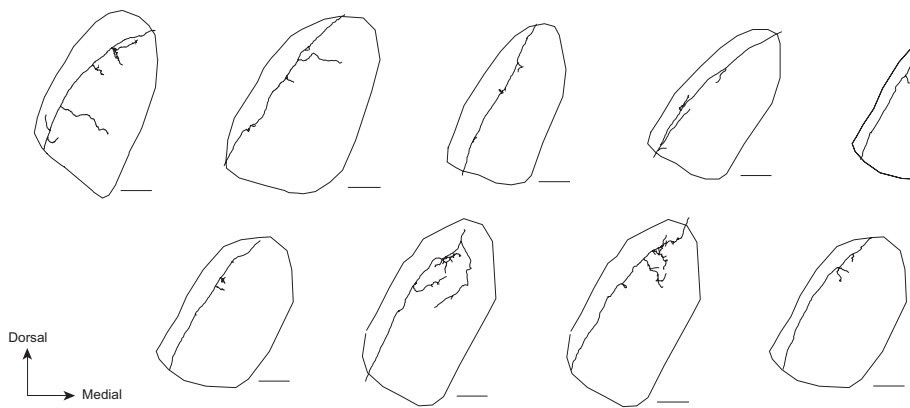

B Postnatal Day 8/9
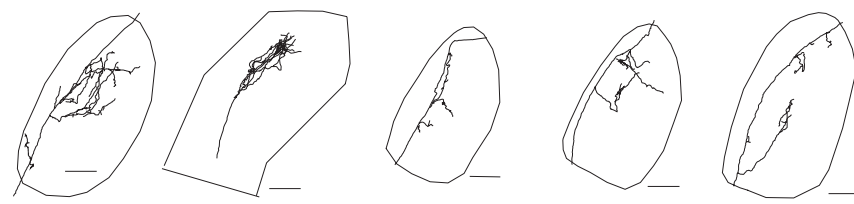

C Postnatal Day 14/15
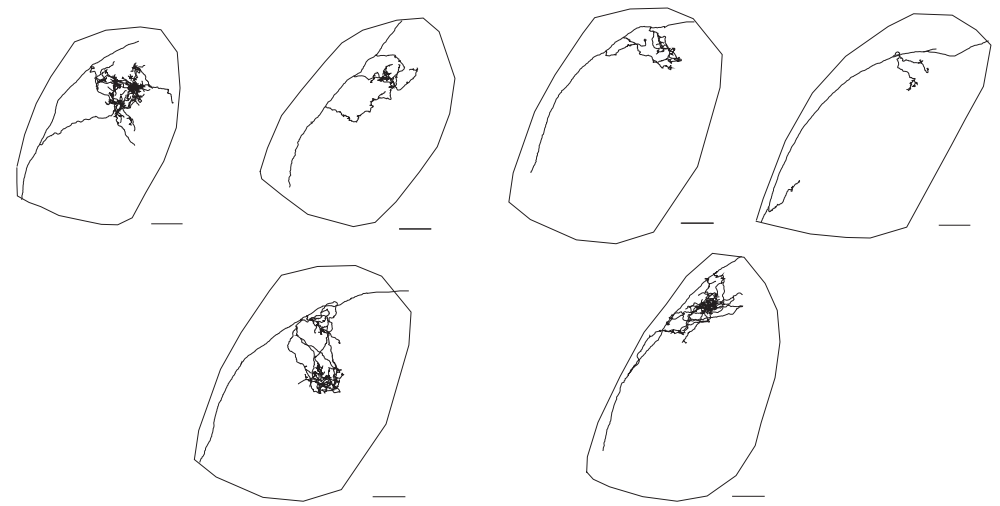

Figure 6. Retinogeniculate axonal arbors in $\beta 2^{-1-}$ mice achieve a level of complexity comparable with WT mice but remain modestly enlarged. Reconstructions of all single ventrotemporal RGC projections in the dLGN (black outline, viewed in coronal plane) at P4 (A), P8/P9 (B), and P14/P15 (C). Scale bars, $100 \mu \mathrm{m}$.

opmental trend to contralateral retinogeniculate arbors. At P4/ P5, ipsilaterally projecting single RGCs had multiple sparse collaterals branching from varying locations along the length of the axon trunk (supplemental Figs. 6A, 7A, available at www. jneurosci.org as supplemental material). At P8/P9, ipsilateral RGC axon arbors displayed a broad range of complexity compared with contralateral axonal arbors, from sparse (two of four) to densely ramified terminals (supplemental Figs. $6 B, 7 B$, available at www.jneurosci.org as supplemental material). By P14/ P15, all ipsilateral RGC arbors were complex and fully innervated their target area forming a dense termination zone (Fig. 5A) (supplemental Fig. 7C, available at www.jneurosci.org as supplemental material). These qualitative assessments are supported by the significant increases in the total arbor length, number of branch points, arbor density, and total area occupied by each arbor between P4/P5 and P14/P15 (supplemental Fig. 8, available at www. jneurosci.org as supplemental material) (Table 3). Changes in the structural parameters measured demonstrate that ipsilateral RGC axon arbors in the dLGN during the first 2 postnatal weeks, like contralateral axon arbors, progressively become spatially restricted and continuously grow to densely innervate their termination zone by eye-opening (approximately P14).
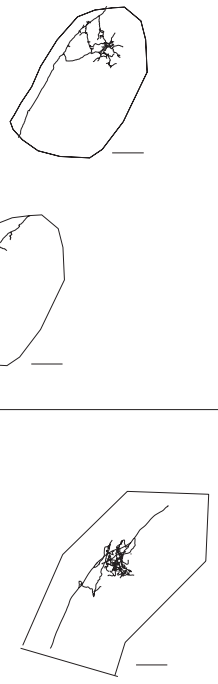

We next analyzed ipsilaterally projecting RGC axon arbors in the SC at the end of the second postnatal week when the retinotopic map is mature. Ipsilateral retinocollicular arbors were labeled, imaged, and quantified in the same manner as described above for contralateral RGC arbors in the SC. Interestingly at P14/P15, ipsilateral RGC axons in the SC were strikingly different from contralateral retinocollicular axons, with a larger rostrocaudal extent and significantly sparser arbors (Fig. 5B-E) (supplemental Fig. 9, available at www.jneurosci.org as supplemental material). In the dLGN, unlike in the SC, both ipsilateral and contralateral retinogeniculate arbors were comparable in their complexity, density, and area at the end of the second postnatal week (compare Fig. $2 C$ with $5 A$ and Fig. $3 D$ with $5 B$ ). The difference in ipsilateral versus contralateral arbors within the SC suggests the existence of mechanisms that uniquely influence axon arbor development depending on eye of origin and target structure.

\section{Development of single RGC arbors in $\boldsymbol{\beta} 2^{-1-}$ mice}

Previous studies using bulk dye labeling methods in $\beta 2^{-1-}$ mice have demonstrated that the segregation of eye-specific inputs and retinotopic map refinement in both the dLGN and SC are perturbed (for review, see Huberman et al., 2008a). Because $\beta 2^{-1-}$ mice have disrupted retinal waves, which may interfere with the normal growth and extension of RGC axon arbors, it remains unclear what structural changes, if any, are occurring at the level of single RGC arbors that result in disrupted subcortical visual maps in the these mice. To examine in detail the structural basis of retinotopic map defects in $\beta 2^{-1-}$ mice, we fluorescently labeled and reconstructed single retinogeniculate and retinocollicular arbors at various developmental time points.

\section{Maturation of RGC arbors in the dLGN of $\beta 2^{-/-}$mice}

Eye-specific segregation of retinal projections in the dLGN is disrupted in $\beta 2^{-I-}$ at the end of first postnatal week and progressively improves to levels comparable with WT mice by P28. However, eye-specific projections fail to segregate into their appropriate lamina, leading to the formation of aberrant "microdomains" of eye-specific projections in the dLGN (MuirRobinson et al., 2002). Retinotopic map refinement is also disrupted in the dLGN of $\beta 2^{-1-}$ mice (Grubb et al., 2003; Pfeiffenberger et al., 2006).

We labeled, reconstructed, and analyzed single contralateral retinogeniculate arbors in $\beta 2^{-/-}$mice at $\mathrm{P} 4, \mathrm{P} 8 / \mathrm{P} 9$, and $\mathrm{P} 14 / \mathrm{P} 15$ and examined their structural development compared with WT arbors in the dLGN at the same age. Individual retinogeniculate axon arbors are moderately disrupted in $\beta 2^{-1-}$ mice (Fig. 6), with significantly larger arbor length and average branch length 
only at the end of the first postnatal week (Fig. $7 \mathrm{~A}, \mathrm{C}$ ). The complexity of single retinogeniculate arbors in $\beta 2^{-1-}$ mice is comparable with WT arbors at all ages (compare arbors in Figs. 2, 6; Fig. 7B). Although average arbor area tended to be larger in $\beta 2^{-1-}$ at the end of the first and second postnatal week, this difference was only statistically significant at P8/P9 (Fig. $7 D, F)$.

Although bulk labeling methods have demonstrated a significant disruption in the refinement of visual maps in the dLGN of $\beta 2^{-/-}$mice during the first 2 postnatal weeks (Muir-Robinson et al., 2002; Grubb et al., 2003; Pfeiffenberger et al., 2006), at the level of individual retinogeniculate arbors, we find that the structural changes are less dramatic than previously predicted. Quantitative analysis of single retinogeniculate arbors in $\beta 2^{-I-}$ mice demonstrates that growth and structural maturation of retinal axon arbors occurs even in the absence of normal spontaneous retinal activity, although ramification within the appropriate termination zone is disrupted. Changes in RGC axon arbor area in the dLGN observed in $\beta 2^{-1-}$ mice over the course of the first 2 postnatal weeks are consistent with previous observations that segregation of eye-specific inputs improves in $\beta 2^{-1-}$ mice during the second postnatal week (Muir-Robinson et al., 2002). However, the quantitative changes in the various structural parameters measured for single retinogeniculate arbors in $\beta 2^{-1-}$ mice seem insufficient to explain the persistence of perturbed retinotopy and disrupted eye-specific lamination in the dLGN. This discrepancy suggests that, in addition to modestly larger individual arbors, arbors originating from neighboring RGCs in $\beta 2^{-1-}$ mice are partially misaligned and do not fully overlap, which produces the larger target zones observed with bulk DiI labeling techniques (Grubb et al., 2003; Pfeiffenberger et al., 2006).

\section{Development of single RGC arbors in the SC of $\beta 2^{-/-}$mice}

Bulk labeling of large populations of RGCs reveals that retinotopic refinement and eye-specific projections to the SC are disrupted in $\beta 2^{-/-}$mice (Rossi et al., 2001; McLaughlin et al., 2003; Chandrasekaran et al., 2005; Pfeiffenberger et al., 2006). We reconstructed single retinocollicular arbors in $\beta 2^{-1-}$ mice at multiple time points during development to examine the effects of the $\beta 2^{-1-}$ mutation on the development of single RGC axon arbors in the SC.
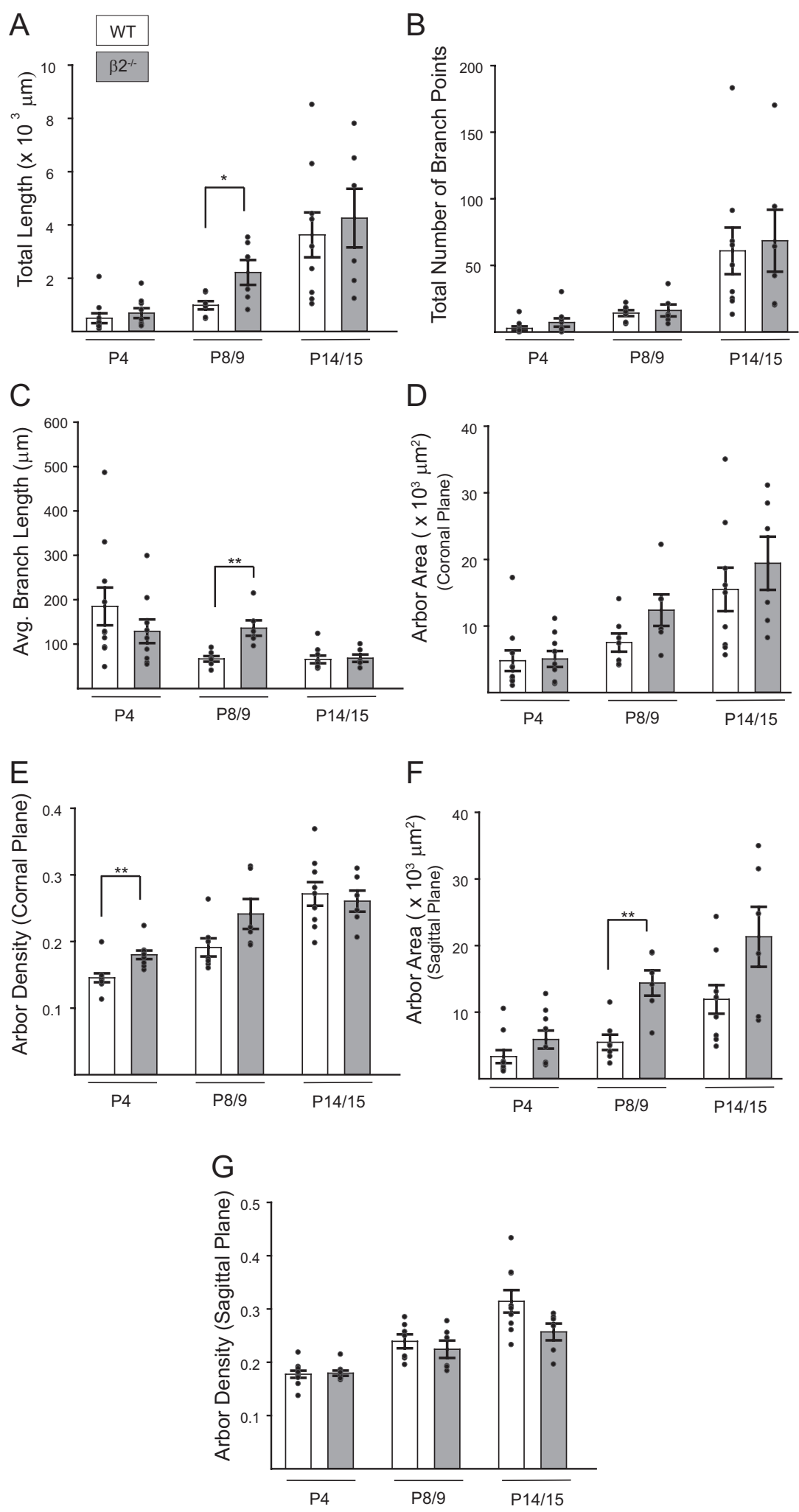

Figure 7. Quantification and comparative analysis of the maturation of single retinogeniculate arbors in WT and $\beta 2^{-/-}$mice. $A$, Quantification of total length of reconstructed RGC arbors in the dLGN of WT (white bars) and $\beta 2^{-1-}$ (light gray bars) mice. $\boldsymbol{B}$, Total number of branch points. $\boldsymbol{C}$, Average branch length. $\boldsymbol{D}, \boldsymbol{F}$, Average area of coronal $(\boldsymbol{D})$ and sagittal $(\boldsymbol{F})$ projection of 3-D arbor reconstructions. $\boldsymbol{E}, \boldsymbol{G}$, Mean density of coronal $(\boldsymbol{E})$ and sagittal $(\boldsymbol{G})$ projection of 3-D arbor reconstructions. At all ages, arbors are similar to WT arbors in regards to complexity $(\boldsymbol{B}, \boldsymbol{E}, \boldsymbol{F})$. However, they appear to overgrow and tend to occupy a larger area relative to WT arbors $(\boldsymbol{A}, \boldsymbol{D}, \boldsymbol{C}, \boldsymbol{F})$. Bars represent mean, and red circles are individual data points. Error bars indicate SEM. ${ }^{*} p<0.05 ;{ }^{* *} p<$ $0.01 ;{ }^{* * *} p<0.001$. 


\section{A Postnatal Day 2}

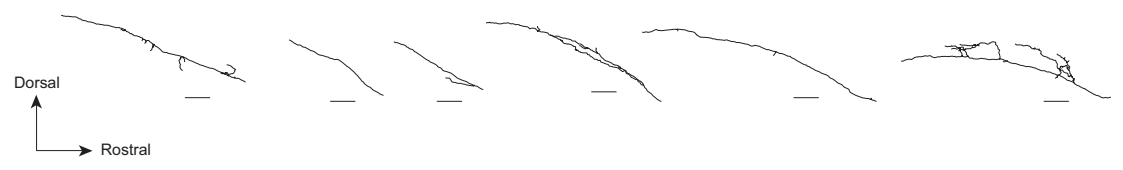

\section{B Postnatal Day 4}
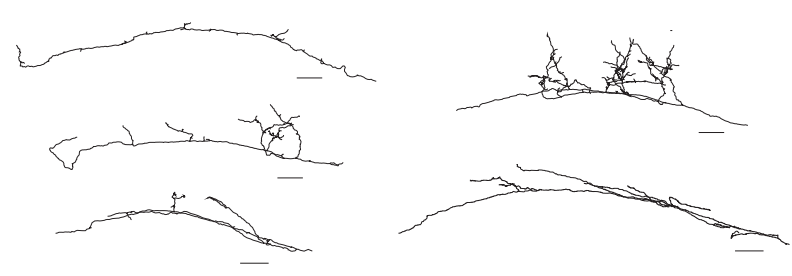

C Postnatal Day $8 / 9$
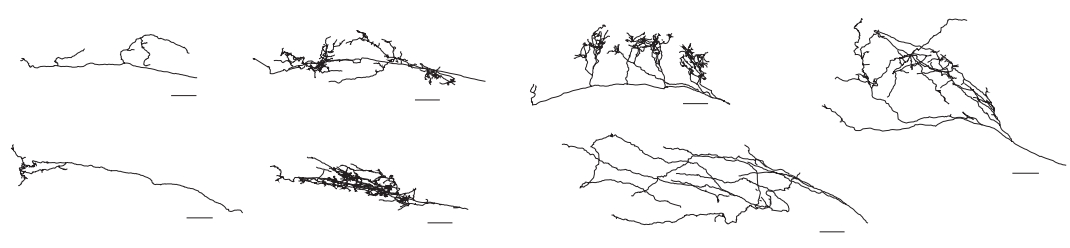

D Postnatal Day $14 / 15$
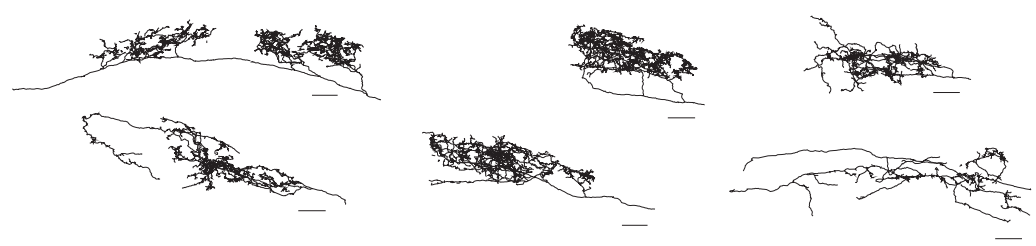

Figure 8. Single retinocollicular arbors in $\beta 2^{-1-}$ mice fail to undergo refinement and elaborate to occupy a larger area compared with WT retinocollicular arbors. Reconstructions of all single temporal RGC projections in the SC (sagittal plane) at P2 $(\boldsymbol{A})$, $\mathrm{P} 4(\boldsymbol{B}), \mathrm{P} 8 / \mathrm{P} 9(\boldsymbol{C})$, and P14/P15 (D). $\beta 2^{-/-}$retinocollicular axons fail to both eliminate inappropriately located sparse collaterals and form a coarse target zone in the anterior colliculus by $P 4(\boldsymbol{A}, \boldsymbol{B})$. Retinocollicular arbors in $\beta 2^{-/-}$mice continue to elaborate during the first 2 weeks after birth, resulting in elongated and enlarged arbors $(\boldsymbol{C}, \boldsymbol{D})$. Scale bars, $100 \mu \mathrm{m}$.

At P2, RGC axons in $\beta 2^{-1-}$ mice are indistinguishable from WT axons, with simple and very sparse arbors that overshoot their correct termination zone (Figs. 8A, 9F; Table 2) (supplemental Fig. $11 A$, available at www.jneurosci.org as supplemental material). At P4, unlike WT axons, $\beta 2^{-1-}$ axons appear to maintain and elaborate inappropriately located collaterals. Between P4 and P8/P9, unlike WT axons, $\beta 2^{-1-}$ axon development stalls, with no apparent elimination of inappropriately located collaterals or significant increase in arbor length, number of branch points, or decrease in average branch length (Figs. $8 B, C$, 9; Table 2) (supplemental Fig. $11 B, C$, available at www.jneurosci.org as supplemental material). During the second postnatal week, $\beta 2^{-1-}$ axon development partially resumes, and axon arbors become still larger and more dense along the entire length of the axon, although they never reach the level of focused complexity observed in WT axons (Figs. 8D, 9; Table 2) (supplemental Fig. $11 D$, available at www.jneurosci.org as supplemental material). The surface area occupied by $\beta 2^{-l-}$ arbors is also larger compared with WT arbors at eye opening (Fig. 9E; Table 2). Interestingly, arbors in $\beta 2^{-1-}$ mice remain preferentially elongated along the RC extent throughout the first 2 postnatal weeks,

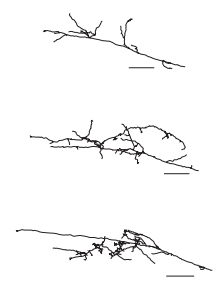

although they appear to remain restricted along the ML axis (Fig. 9F; Table 2).

These results suggest that altered retinal activity in $\beta 2^{-1-}$ mice does not prevent RGC arbors in the SC from growing and elaborating. However, the focused increase in arbor density in the correct topographic region observed in WT mice is impaired in $\beta 2^{-1-}$ mice. Also, during early development, the retraction and elimination of inappropriate branches fails to occur in $\beta 2^{-l-}$ mice, and these topographically inaccurate branches subsequently elaborate, albeit at a slower rate throughout the first 2 postnatal weeks, leading to larger and sparser arbors than observed in WT mice.

\section{Discussion}

\section{Genetically targeting single RGCs}

The refinement of sensory maps is generally considered to be a reflection of the structural rearrangement of individual axons that is governed in part by activitydependent competition (Hua et al., 2005; Cao et al., 2007; Ben Fredj et al., 2010). These studies were possible primarily because of the availability of cell-typespecific promoters and transgenics that allow for the expression of exogenous genes in single cells. However, the lack of comparable genetic tools has been a hindrance in studying similar phenomena in the mammalian visual system. We demonstrate a fast, relatively efficient and cost-effective method to genetically manipulate single and small clusters of RGCs at any age via postnatal in vivo electroporation. This method should be invaluable for future experiments probing the rules and mechanisms regulating visual map structure and development in the mammalian retinofugal system.

Given that we used a ubiquitous promoter and there are at least 13 different classes of RGCs in the mouse (Diao et al., 2004), we expect and observed a great deal of heterogeneity in RGC dendritic and axon morphology. Qualitatively, we found that the vast majority of labeled RGC axons projected to both the dLGN and SC, far fewer projected to only the SC and very rarely did we observe axons that terminated only in the dLGN (and not the SC or pretectal area). The method used in this study likely samples different RGC subtypes randomly but could be biased by unknown factors that influence the efficiency of electroporation. A more refined approach using cell-type-specific promoters should permit examination of specific RGC subtypes over development.

\section{Development of WT retinofugal arbors}

Our results demonstrate that RGC arbors form collaterals at multiple points along the length of the axon that then converge to form a single confined termination zone that becomes progressively denser and spatially restricted over the course of development. This is consistent with previous reports on retinofugal 

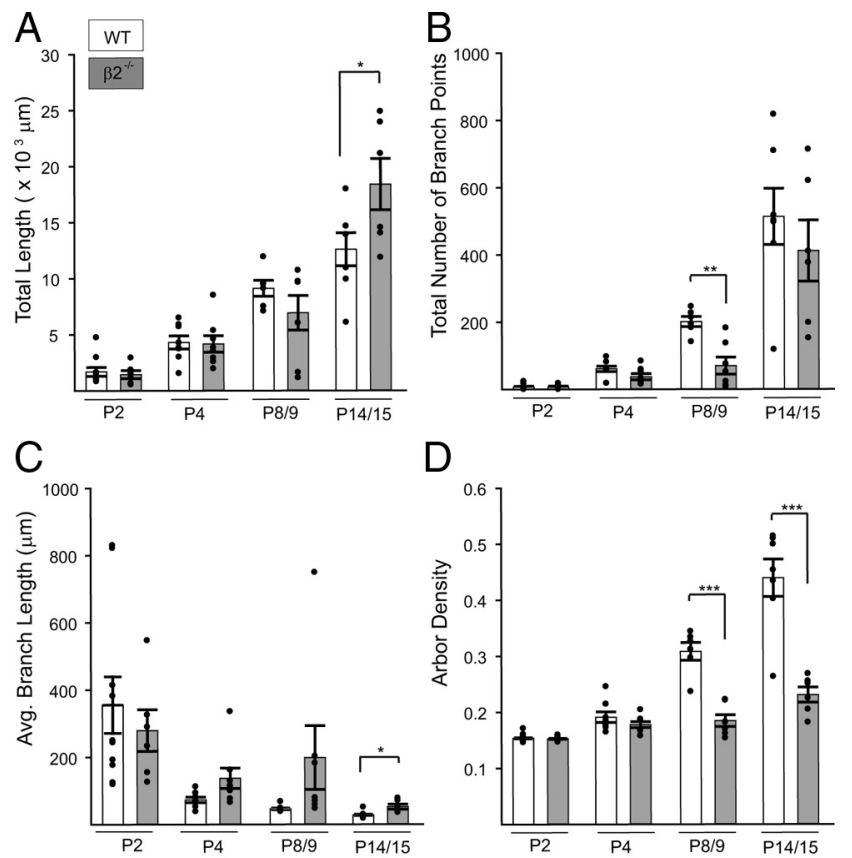

$\mathrm{D}$
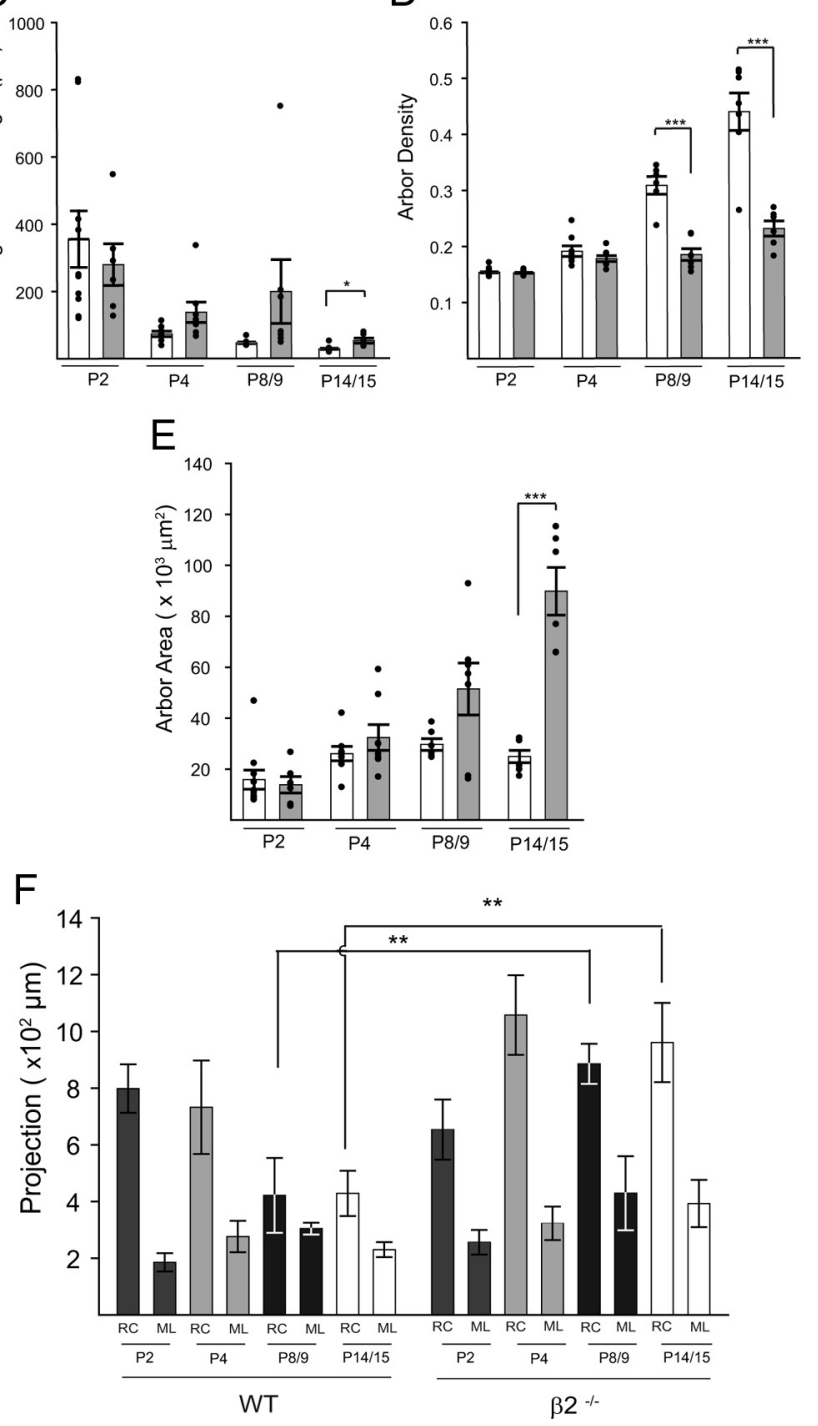

Figure 9. Quantitative analysis of the development of single retinocollicular axons demonstrates that arbor refinement but not growth is perturbed in $\beta 2^{-l-}$ mice. $A$, Quantification of total length. $\boldsymbol{B}$, Total number of branch points. $\boldsymbol{C}$, Average branch length. $\boldsymbol{D}$, Mean arbor density. $\boldsymbol{E}$, Average arbor area. $\boldsymbol{F}$, Rostrocaudal and mediolateral projections of single RGC axon arbors at P2 (dark gray), P4 (light gray), P8/P9 (black), and P14/P15 (white) in the WT and $\beta 2^{-1-}$ SC. Bars represent mean, and red circles are individual data points. Error bars indicate SEM. ${ }^{*} p<$ $0.05 ;{ }^{* *} p<0.01 ;{ }^{* * *} p<0.001$.

arbor development using alternative labeling techniques in mice and other higher vertebrate species (monkey: Conley and Fitzpatrick, 1989; Snider et al., 1999; cat: Sretavan and Shatz 1984, 1986, 1987; ferret: Hahm et al., 1999; hamster: Bhide and Frost, 1991; Jhaveri et al., 1991; mice: Iwahori and Mizuno 1984; Sachs et al.,
1986; Simon and O'Leary 1992; Nicol et al., 2006). We have significantly extended these studies by performing a quantitative analysis of the following: (1) clearly identified and complete single RGC axon arbors over a wide range of ages; (2) RGC axon arbor development in the dLGN versus SC; and (3) contralateral versus ipsilateral axon arbors.

Despite the general similarities in the developmental profile of RGC axon arbors in the dLGN and SC, there are clear differences that were unanticipated. The formation of a dense termination zone by retinogeniculate arbors appears to lag behind retinocollicular arbors by almost 1 week. Generally, timing differences in the arrival of RGC axons in their target are correlated with their level of structural maturity, with late-arriving axons being more immature than early arriving RGC axons (Sretavan and Shatz, 1987). However, the early development of murine RGC arbors in the SC cannot be a consequence of a difference in target arrival time as RGC axons pass over the LGN before they reach the SC and invade both the SC and dLGN embryonically (approximately embryonic day 16) (Godement et al., 1984). Moreover, collicular and geniculate arbors from the same RGC axon showed targetspecific differences in the timing of their elaboration. The differences in developmental timing may be attributable to target-derived factors or differences in intracollicular and intrageniculate network activity. Overall, comparing retinogeniculate and retinocollicular arbor development suggests that there are different "critical periods" for arbor refinement in the dLGN and SC.

In the cat, contralateral arbor development leads ipsilateral axons in the dLGN by several days, which approximately matches their early arrival, although the final structure of arbors is similar (Sretavan and Shatz, 1987). In mice, we found that ipsilateral and contralateral arbor development in the dLGN is quite similar, in both time course and final structure, despite the delayed arrival of ipsilateral axons to the dLGN (Godement et al., 1984). In the SC, ipsilateral arbors are remarkably sparse and expanded along the rostrocaudal axis compared with contralateral arbors. The difference in ipsilateral axons in the dLGN and SC could be attributable to targetderived factors that are related to the distinctly different nature and geometry of the regions in the dLGN and SC within which eye-specific projections terminate in mice.

Our retinofugal axon reconstructions are confined to RGC axons from the ventrotemporal retina, which must "fight for space" with RGC axons from the opposing eye. This may influence both the final structure and the pace of their development relative to axons from other parts of the retina. Similarly, differences in RGC axon projections to and within the dLGN and SC could arise from intrinsically different RGC subtypes that project to these different targets (Huberman et al., 2008b, 2009; Kim et al., 2008, 2010).

\section{Arbor development in $\boldsymbol{\beta} 2^{-/-}$mice}

Waves of correlated activity traverse the retina during visual system development in a number of vertebrate organisms, including rats, mice, rabbits, cats, and fetal macaque monkeys. In mice, retinal waves are dependent on $n A C h R s$ during the first postnatal week and become dependent on glutamatergic signaling during the second postnatal week (Blankenship and Feller, 2010). Eyespecific segregation and topographic refinement of the retinocollicular map is perturbed in mice with altered cholinergic retinal waves ( $\beta 2^{-/-}$mice) as evidenced by bulk labeling of RGC axon terminals (Muir-Robinson et al., 2002; McLaughlin et al., 2003; Chandrasekaran et al., 2005). Multiple scenarios could poten- 
tially explain the enlarged RGC axon termination zones in $\beta 2^{-/-}$ mice. The position of individual RGC arbors could be shifted in relation to neighboring axons, leading to enlarged terminal zones without effecting single axon arbor areas (Gnuegge et al., 2001; Hua et al., 2005; Ben Fredj et al., 2010). Abnormal spontaneous retinal activity may also interfere with cellular signaling pathways that are essential for normal arbor growth, resulting in sparse, poorly ramified and enlarged target zones (Torborg and Feller, 2005; Chalupa, 2009). Finally, enlarged termination zones could be the consequence of individual RGC axon arbors that are highly ramified but cover large areas. This latter explanation is suggested by Hebbian models in which correlated retinal activity drives the selective stabilization and elimination of synapses through synaptic learning rules, and, in the absence of an instructive signal from retinal waves, axons elaborate at inappropriate locations (Shah and Crair, 2009).

In the SC, we demonstrate that $\beta 2^{-1-}$ mice have much larger individual RGC axon arbors, although local targeting errors of these enlarged arbors may also contribute to visual map phenotypes in $\beta 2^{-1-}$ mice. Even in the absence of normal spontaneous retinal activity, RGC arbors are able to grow and elaborate, but they appear to lack a "stop signal" and continue to grow and elaborate in topographically inappropriate locations. These observations are consistent with previous studies in which the pharmacological blockade of retinal activity does not prevent RGC arbors from growing but instead leads to enlarged and misprojecting arbors (Sretavan et al., 1988; Thompson and Holt 1989). In $\beta 2^{-1-}$ mice, the receptive fields of SC neurons and RGC termination zones in the SC are preferentially elongated along the rostrocaudal axis relative to the mediolateral axis (Chandrasekaran et al., 2005; Mrsic-Flogel et al., 2005; Wang et al., 2009). We find the same asymmetry in $\beta 2^{-/-}$mice even at the level of single axons, with retinocollicular arbors preferentially elongated along the rostrocaudal axis. This asymmetry could be attributable to an intrinsic asymmetry in the direction of retinal waves (Stafford et al., 2009) or a greater dependence of RGC axon targeting on activity-dependent factors along the rostrocaudal axis, because RGC axons are partially sorted along the mediolateral in the optic tract before reaching their target in the SC (Plas et al., 2005, 2008).

In the dLGN of $\beta 2^{-1-}$ mice, single RGC axon arbors are only modestly affected compared with the SC. At P8, RGC arbors in the dLGN occupy a larger area in $\beta 2^{-/-}$mice, but this difference is small and transient so that, by P14, they are not statistically different from WT mice. Thus, RGC axons in the dLGN of $\beta 2^{-1-}$ mice are able to grow, elaborate, and develop arbors that are of similar complexity as WT mice, but mapping defects in the dLGN may be caused by axon targeting errors instead of gross enlargement of individual arbors. The more modest single axon phenotypes in the dLGN compared with the SC are consistent with the similarly modest phenotypes assayed with bulk labeling and functional methods (Muir-Robinson et al., 2002; Grubb et al., 2003; Cang et al., 2005; Chandrasekaran et al., 2005; Pfeiffenberger et al., 2006). This may be attributable to the relatively late development of retinogeniculate projections, which permits second week glutamatergic waves to play a greater role in correcting initial defects in arbor structure and visual map development in the dLGN of $\beta 2^{-1-}$ mice.

\section{Relating retinofugal axon arbor and synapse development}

Electrophysiological examination of retinofugal synapse development suggests that connections increase in strength and the number of synaptic connections per target neuron de- creases during the first 2 weeks after birth (Chen and Regehr, 2000; Lo et al., 2002; Hooks and Chen, 2006; Ziburkus and Guido, 2006; Chandrasekaran et al., 2007; Shah and Crair, 2008). Retinocollicular synapse development in particular occurs principally during the first postnatal week (Chandrasekaran et al., 2007; Shah and Crair 2008), whereas retinogeniculate synapse development occurs primarily in the second and third week (Chen and Regehr, 2000; Lo et al., 2002; Hooks and Chen 2006; Ziburkus and Guido, 2006). This corresponds nicely with the delayed development of retinogeniculate axon arbors relative to retinocollicular arbors. In $\beta 2^{-1-}$ mice, there is also a reasonable correspondence between the delayed electrophysiological development of retinocollicular synapses (Shah and Crair, 2008) and the delayed anatomical elaboration of retinocollicular axon arbors described here.

There is, however, a notable difference between the development of retinofugal synaptic physiology and anatomy. Axon arbors increase in complexity throughout the first 2 weeks after birth, with the number of branch points (and presumably synapses) increasing by more than a factor of 10 in both the dLGN and SC. In contrast, electrophysiological studies show that there is a "refinement" in retinofugal synapses, with the number of RGC inputs per dLGN/SC neuron actually decreasing significantly during this time. There are at least three possible explanations for this discrepancy. First, the number of RGC neurons projecting to the dLGN and SC may decrease, leaving fewer total synapses from all RGCs, despite the apparent anatomical increase in synapses per RGC. Second, the number of neurons in the dLGN and SC could increase, providing more targets for the increasingly complex RGC axon arbors. Third, the number of synapses between specific pairs of RGCs and target neurons could increase dramatically, while at the same time the number of RGCs that synapse on a given target neuron in the dLGN and SC decreases. That is, RGCs could be making more synapses but onto a decreasing subset of dLGN/SC neurons. We favor this latter explanation, but all three factors may play a role in retinofugal development.

\section{Summary}

Our findings demonstrate that, before vision, individual RGC projections dramatically reorganize. Retinocollicular and retinogeniculate projections significantly increase in their complexity in the correct target region while eliminating sparse inappropriate collateral branches. Surprisingly, we find that retinogeniculate arbors mature $\sim 1$ week later than retinocollicular arbors. We also observed that ipsilateral RGC axon arbors in the dLGN are comparable with contralateral arbors, but in the SC ipsilateral arbors are strikingly simple and sparser than contralateral arbors. These results imply that factors intrinsic to the dLGN and SC play an important role in retinofugal arbor development. Last, we demonstrated that individual RGC axon arbors in mice with perturbed retinal waves $\left(\beta 2^{-l-}\right)$ are dramatically enlarged but still complex in the SC, with more muted effects in the dLGN, providing a structural explanation for the altered visual maps observed in these mice.

\section{References}

Antonini A, Stryker MP (1993) Development of individual geniculocortical arbors in cat striate cortex and effects of binocular impulse blockade. J Neurosci 13:3549-3573.

Ben Fredj N, Hammond S, Otsuna H, Chien CB, Burrone J, Meyer MP 
(2010) Synaptic activity and activity-dependent competition regulates axon arbor maturation, growth arrest, and territory in the retinotectal projection. J Neurosci 30:10939-10951.

Bhide PG, Frost DO (1991) Stages of growth of hamster retinofugal axons: implications for developing axonal pathways with multiple targets. J Neurosci 11:485-504.

Blankenship AG, Feller MB (2010) Mechanisms underlying spontaneous patterned activity in developing neural circuits. Nat Rev Neurosci $11: 18-29$.

Cang J, Rentería RC, Kaneko M, Liu X, Copenhagen DR, Stryker MP (2005) Development of precise maps in visual cortex requires patterned spontaneous activity in the retina. Neuron 48:797-809.

Cao L, Dhilla A, Mukai J, Blazeski R, Lodovichi C, Mason CA, Gogos JA (2007) Genetic modulation of BDNF signaling affects the outcome of axonal competition in vivo. Curr Biol 17:911-921.

Cerda GA, Thomas JE, Allende ML, Karlstrom RO, Palma V (2006) Electroporation of DNA, RNA, and morpholinos into zebrafish embryos. Methods 39:207-211.

Chalupa LM (2009) Retinal waves are unlikely to instruct the formation of eye-specific retinogeniculate projections. Neural Dev 4:25.

Chandrasekaran AR, Plas DT, Gonzalez E, Crair MC (2005) Evidence for an instructive role of retinal activity in retinotopic map refinement in the superior colliculus of the mouse. J Neurosci 25:6929-6938.

Chandrasekaran AR, Shah RD, Crair MC (2007) Developmental homeostasis of mouse retinocollicular synapses. J Neurosci 27:1746-1755.

Chen C, Regehr WG (2000) Developmental remodeling of the retinogeniculate synapse. Neuron 28:955-966.

Conley M, Fitzpatrick D (1989) Morphology of retinogeniculate axons in the macaque. Vis Neurosci 2:287-296.

Dezawa M, Takano M, Negishi H, Mo X, Oshitari T, Sawada H (2002) Gene transfer into retinal ganglion cells by in vivo electroporation: a new approach. Micron 33:1-6.

Diao L, Sun W, Deng Q, He S (2004) Development of the mouse retina: emerging morphological diversity of the ganglion cells. J Neurobiol 61:236-249.

Garcia-Frigola C, Carreres MI, Vegar C, Herrera E (2007) Gene delivery into mouse retinal ganglion cells by in utero electroporation. BMC Dev Biol 7:103.

Gnuegge L, Schmid S, Neuhauss SC (2001) Analysis of the activity-deprived zebrafish mutant macho reveals an essential requirement of neuronal activity for the development of a fine-grained visuotopic map. J Neurosci 21:3542-3548.

Godement P, Salaün J, Imbert M (1984) Prenatal and postnatal development of retinogeniculate and retinocollicular projections in the mouse. J Comp Neurol 230:552-575.

Grubb MS, Rossi FM, Changeux JP, Thompson ID (2003) Abnormal functional organization in the dorsal lateral geniculate nucleus of mice lacking the beta 2 subunit of the nicotinic acetylcholine receptor. Neuron 40:1161-1172.

Haas K, Sin WC, Javaherian A, Li Z, Cline HT (2001) Single-cell electroporation for gene transfer in vivo. Neuron 29:583-591.

Hahm JO, Cramer KS, Sur M (1999) Pattern formation by retinal afferents in the ferret lateral geniculate nucleus: developmental segregation and the role of $N$-methyl-D-aspartate receptors. J Comp Neurol 411:327-345.

Hooks BM, Chen C (2006) Distinct roles for spontaneous and visual activity in remodeling of the retinogeniculate synapse. Neuron 52:281-291.

Hua JY, Smear MC, Baier H, Smith SJ (2005) Regulation of axon growth in vivo by activity-based competition. Nature 434:1022-1026.

Huberman AD, Murray KD, Warland DK, Feldheim DA, Chapman B (2005) Ephrin-As mediate targeting of eye-specific projections to the lateral geniculate nucleus. Nat Neurosci 8:1013-1021.

Huberman AD, Feller MB, Chapman B (2008a) Mechanisms underlying development of visual maps and receptive fields. Annu Rev Neurosci 31:479-509.

Huberman AD, Manu M, Koch SM, Susman MW, Lutz AB, Ullian EM, Baccus SA, Barres BA (2008b) Architecture and activity-mediated refinement of axonal projections from a mosaic of genetically identified retinal ganglion cells. Neuron 59:425-438.

Huberman AD, Wei W, Elstrott J, Stafford BK, Feller MB, Barres BA (2009) Genetic identification of an On-Off direction-selective retinal ganglion cell subtype reveals a layer-specific subcortical map of posterior motion. Neuron 62:327-334.
Iwahori N, Mizuno N (1984) The dorsal lateral geniculate nucleus in the mouse: a Golgi study. Neurosci Res 1:433-455.

Jhaveri S, Edwards MA, Schneider GE (1991) Initial stages of retinofugal axon development in the hamster: evidence for two distinct modes of growth. Exp Brain Res 87:371-382.

Kim IJ, Zhang Y, Yamagata M, Meister M, Sanes JR (2008) Molecular identification of a retinal cell type that responds to upward motion. Nature 452:478-482.

Kim IJ, Zhang Y, Meister M, Sanes JR (2010) Laminar restriction of retinal ganglion cell dendrites and axons: subtype-specific developmental patterns revealed with transgenic markers. J Neurosci 30:1452-1462.

Lo FS, Ziburkus J, Guido W (2002) Synaptic mechanisms regulating the activation of a $\mathrm{Ca}^{2+}$-mediated plateau potential in developing relay cells of the LGN. J Neurophysiol 87:1175-1185.

Matsuda T, Cepko CL (2004) Electroporation and RNA interference in the rodent retina in vivo and in vitro. Proc Natl Acad Sci U S A 101:16-22.

Matsuda T, Cepko CL (2007) Controlled expression of transgenes introduced by in vivo electroporation. Proc Natl Acad Sci USA 104:1027-1032.

McLaughlin T, O'Leary DD (2005) Molecular gradients and development of retinotopic maps. Annu Rev Neurosci 28:327-355.

McLaughlin T, Torborg CL, Feller MB, O'Leary DD (2003) Retinotopic map refinement requires spontaneous retinal waves during a brief critical period of development. Neuron 40:1147-1160.

Mrsic-Flogel TD, Hofer SB, Creutzfeldt C, Cloëz-Tayarani I, Changeux JP, Bonhoeffer T, Hübener M (2005) Altered map of visual space in the superior colliculus of mice lacking early retinal waves. J Neurosci 25:6921-6928.

Muir-Robinson G, Hwang BJ, Feller MB (2002) Retinogeniculate axons undergo eye-specific segregation in the absence of eye-specific layers. J Neurosci 22:5259-5264.

Nicol X, Muzerelle A, Rio JP, Métin C, Gaspar P (2006) Requirement of adenylate cyclase 1 for the ephrin-A5-dependent retraction of exuberant retinal axons. J Neurosci 26:862-872.

Okada A, Lansford R, Weimann JM, Fraser SE, McConnell SK (1999) Imaging cells in the developing nervous system with retrovirus expressing modified green fluorescent protein. Exp Neurol 156:394-406.

Pfeiffenberger C, Yamada J, Feldheim DA (2006) Ephrin-As and patterned retinal activity act together in the development of topographic maps in the primary visual system. J Neurosci 26:12873-12884.

Plas DT, Lopez JE, Crair MC (2005) Pretarget sorting of retinocollicular axons in the mouse. J Comp Neurol 491:305-319.

Plas DT, Dhande OS, Lopez JE, Murali D, Thalier C, Henkemeyer M, Furuta Y, Overbeek P, Crair MC (2008) Bone morphogenic proteins, eye patterning, and retinocollicular map formation in the mouse. J Neurosci 28:7057-7067.

Rebsam A, Petros TJ, Mason CA (2009) Switching retinogeniculate axon laterality leads to normal targeting but abnormal eye-specific segregation that is activity dependent. J Neurosci 29:14855-14863.

Rossi FM, Pizzorusso T, Porciatti V, Marubio LM, Maffei L, Changeux JP (2001) Requirement of the nicotinic acetylcholine receptor beta 2 subunit for the anatomical and functional development of the visual system. Proc Natl Acad Sci U S A 98:6453-6458.

Sachs GM, Jacobson M, Caviness VS Jr (1986) Postnatal changes in arborization patterns of murine retinocollicular axons. J Comp Neurol 246:395-408.

Shah RD, Crair MC (2008) Retinocollicular synapse maturation and plasticity are regulated by correlated retinal waves. J Neurosci 28:292-303.

Shah RD, Crair MC (2009) Long-term potentiation and long-term depression in experience-dependent plasticity. In: Encyclopedia of neuroscience (Squire L, ed), Vol 5, pp 561-570. Oxford: Academic.

Simon DK, O'Leary DD (1992) Development of topographic order in the mammalian retinocollicular projection. J Neurosci 12:1212-1232.

Snider CJ, Dehay C, Berland M, Kennedy H, Chalupa LM (1999) Prenatal development of retinogeniculate axons in the macaque monkey during segregation of binocular inputs. J Neurosci 19:220-228.

Sretavan D, Shatz CJ (1984) Prenatal development of individual retinogeniculate axons during the period of segregation. Nature 308:845-848.

Sretavan DW, Shatz CJ (1986) Prenatal development of retinal ganglion cell axons: segregation into eye-specific layers within the cat's lateral geniculate nucleus. J Neurosci 6:234-251. 
Sretavan DW, Shatz CJ (1987) Axon trajectories and pattern of terminal arborization during the prenatal development of the cat's retinogeniculate pathway. J Comp Neurol 255:386-400.

Sretavan DW, Shatz CJ, Stryker MP (1988) Modification of retinal ganglion cell axon morphology by prenatal infusion of tetrodotoxin. Nature 336:468-471.

Stafford BK, Sher A, Litke AM, Feldheim DA (2009) Spatial-temporal patterns of retinal waves underlying activity-dependent refinement of retinofugal projections. Neuron 64:200-212.

Thompson I, Holt C (1989) Effects of intraocular tetrodotoxin on the development of the retinocollicular pathway in the Syrian hamster. J Comp Neurol 282:371-388.

Torborg CL, Feller MB (2005) Spontaneous patterned retinal activity and the refinement of retinal projections. Prog Neurobiol 76:213-235.
Triplett JW, Owens MT, Yamada J, Lemke G, Cang J, Stryker MP, Feldheim DA (2009) Retinal input instructs alignment of visual topographic maps. Cell 139:175-185.

Wang L, Rangarajan KV, Lawhn-Heath CA, Sarnaik R, Wang BS, Liu X, Cang $J$ (2009) Direction-specific disruption of subcortical visual behavior and receptive fields in mice lacking the $\beta 2$ subunit of nicotinic acetylcholine receptor. J Neurosci 29:12909-12918.

Xu W, Orr-Urtreger A, Nigro F, Gelber S, Sutcliffe CB, Armstrong D, Patrick JW, Role LW, Beaudet AL, De Biasi M (1999) Multiorgan autonomic dysfunction in mice lacking the $\beta 2$ and the $\beta 4$ subunits of neuronal nicotinic acetylcholine receptors. J Neurosci 19:9298-9305.

Ziburkus J, Guido W (2006) Loss of binocular responses and reduced retinal convergence during the period of retinogeniculate axon segregation. J Neurophysiol 96:2775-2784. 